\title{
Catalytic Asymmetric Transfer
}

Hydrogenation of Imines:

\section{Recent Advances}

Francisco Foubelo, ${ }^{*[a]}$ and Miguel Yus ${ }^{[a]}$

Dedicated to Professor Ryoji Noyori

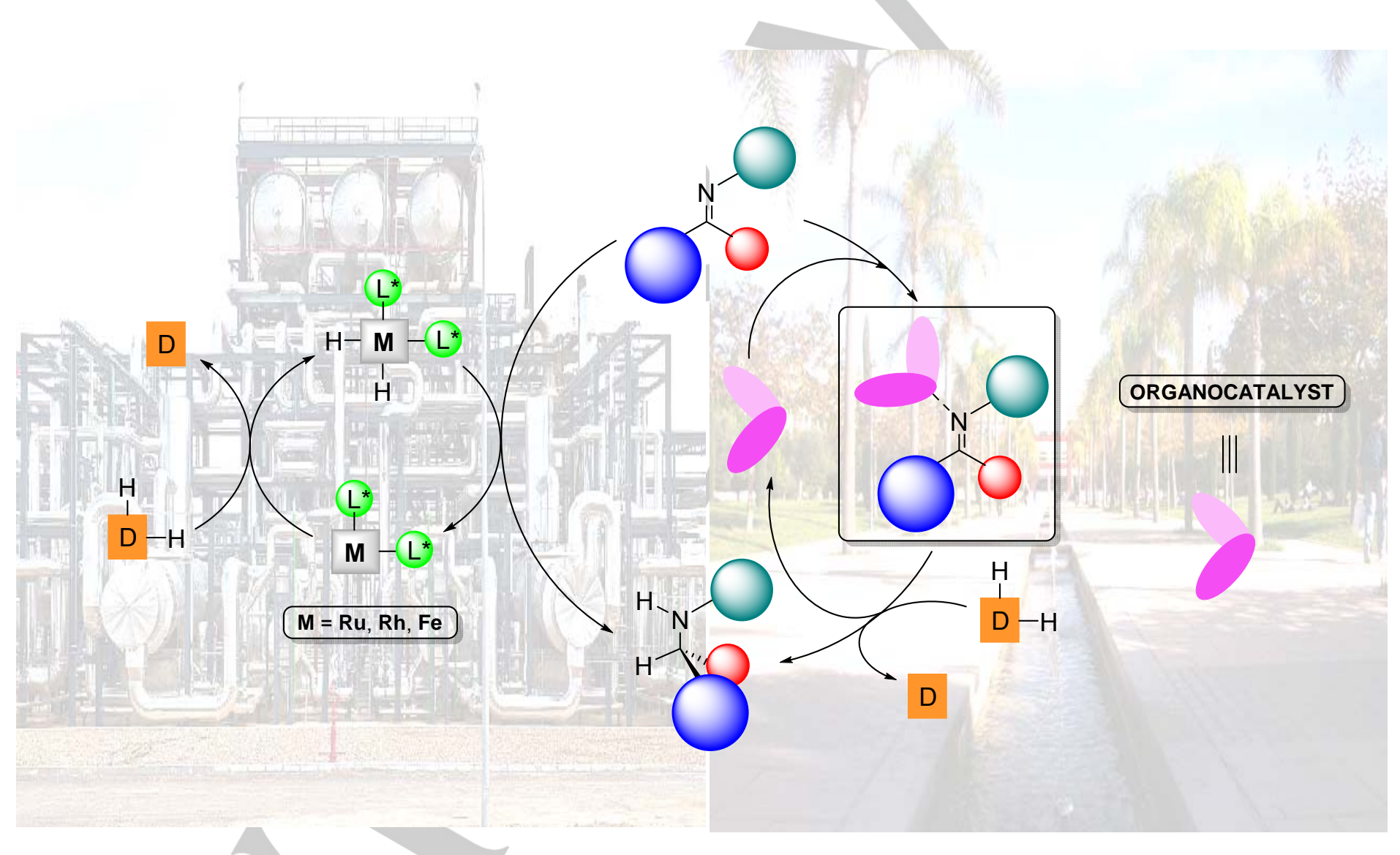


Abstract: In this review article recent developments in the asymmetric transfer hydrogenation of imines from 2008 up today are presented. The main methodology involves either metalcatalyzed procedures in the presence of a chiral ligand or organocatalyzed technologies using a Hantzsch ester and a chiral BINOL-derived phosphoric acid. The most important procedures are collected paying special attention to the synthetic application of this methodology in synthetic organic chemistry.

\section{Introduction}

One important transformation in synthetic organic chemistry is the reduction of imines to amines, which normally is carried out by (i) catalytic hydrogenation with molecular hydrogen, (ii) the use of metal hydrides, and (iii) transfer hydrogenation. ${ }^{1}$ The last method presents some advantages concerning simple manipulation, safety, sustainability and possible industrial applications. ${ }^{2,3}$ Of particular interest is the asymmetric version of this process, namely the asymmetric transfer hydrogenation (ATH) trough which chiral amines are readily available from the corresponding imines, this methodology being an indirect way of transforming carbonyl compounds (the actual precursor of imines) into chiral amines. ${ }^{4}$ For this reaction two general methodologies have been developed, namely (i) the metal catalysis (specially using ruthenium complexes, but also rhodium and iron derivatives) in the presence of a chiral ligand (usually a diamine derivative), or (ii) organocatalysis using a Hantzsch ester and a chiral phosphoric acid. ${ }^{5}$

Concerning the general mechanism of the transfer hydrogenation, as for carbonyl compounds, three possible pathways have been proposed involving a dihydride intermediate (eq a), or a monohydride one through either an inner sphere ligand assistance (eq b) or an outer sphere participation of the ligand (eq c). Scheme 1 shows these variants applied to the use of isopropanol or formic acid as hydrogen sources. ${ }^{2}$

In the present account we report in a non-exhaustive manner the most significant information on the ATH of imines covering the period from 2008 up today, paying special attention of the application of this technology to synthetic organic chemistry leading to enantioenriched amines.

[a] Prof. F. Foubelo and Prof. M. Yus

Departamento de Química Orgánica, Facultad de Ciencias and Centro de Innovación en Química Avanzada (ORFEO-CINQA) Universidad de Alicante

Apdo. 99, 03080 Alicante, Spain

E-mail: foubelo@ua.es,yus@ua.es

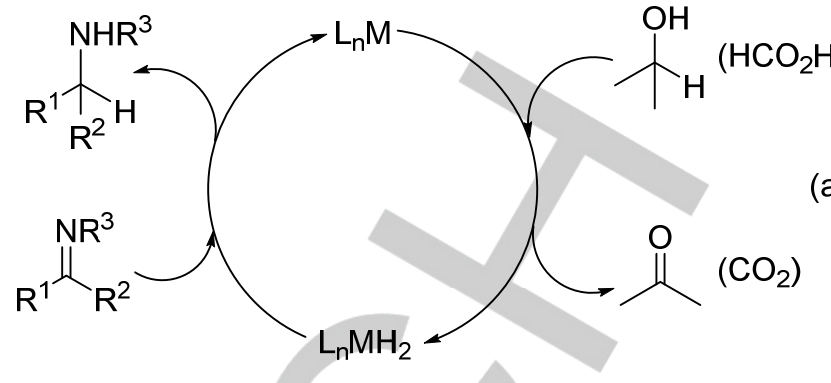

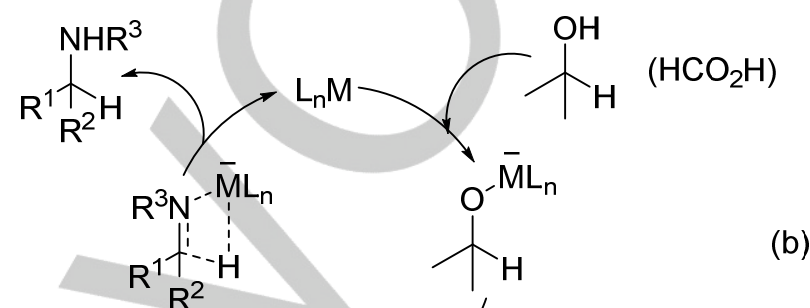

Scheme 1. Proposed mechanisms for the ATH of imines with isopropanol or formic acid as the hydrogen source. ${ }^{2}$

\footnotetext{
Francisco Foubelo studied chemistry at the University of Oviedo from which he received B.S. (1984), M.S. (1986), and Ph.D. (1989) degrees. After that, he spent a postdoctoral stay (1989-1991) as a Fulbright fellow at Princeton University. Then, he moved to the University of Alicante where he became Associate Professor in 1995 and Full Professor in 2002. His research interests are focused on heterofunctionalisation of alkenes and the development of new synthetic methods for asymmetric synthesis related to chiral sulfinimines.
}

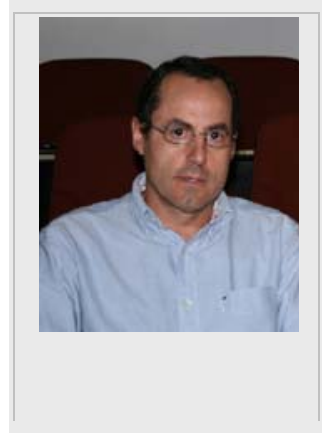


Miguel Yus was born in Saragossa in 1947 and received his BSc (1969), MSc (1971) and PhD (1973) from the University of Saragossa. After spending two years as a postdoctoral fellow at the Max Plack Institut in Mülheim, he became Associate Professor (1977) and Professor (1987) at the University of Oviedo. In 1988 he moved to his current position at the University of Alicante. He has been invited professor at ETH-Zürich, Oxford, Harvard, Uppsala, Tucson, Okayama, Paris, Strasbourg, Bologna, Sassari, Tokyo and Kyoto. Dr. Yus has authored more than 500 papers and five patents, has delivered around 200 lectures abroad and has supervised more than 60 PhD students. Among others he has receive the Spanish-French Prize (1999), twice the Japan Society for the Promotion of Science Prize (2000, 2007), the Stiefvater Memorial Lectureship Award (2001), the Conference Lourenco-Madinaveitia (1912), the Serratosa Lecctureship (2010) and the Medalla Felix Serratosa (2012), being Academician of the European Academy of Sciences and Arts (2012). He has been in the Advisory Bord of about 20 international journals and founded ten years ago the company MEDALCHEMY for the commercialization of fine chemicals.

\section{Reaction Scope: Metal Catalysts and Chiral Ligands}

The ATH of imines has been mainly carried out using organometallic complexes derived from ruthenium, rhodium or in minor extension with iron. Concerning chiral ligands, 1,2aminoalcohols and specially 1,2-diamines and their derivatives have been successfully used for the mentioned reaction.

\subsection{Ruthenium Catalysts}

Monotosylated 1,2-diphenylenediamine (TsDPEN, 1) and their analogues in combination with a ruthenium complex 2 (Noyori's catalysts ${ }^{6}$ ) were very efficient in the ATH of imines, specially for 1-substituted-3,4-dihydroisoquinolines. ${ }^{7}$

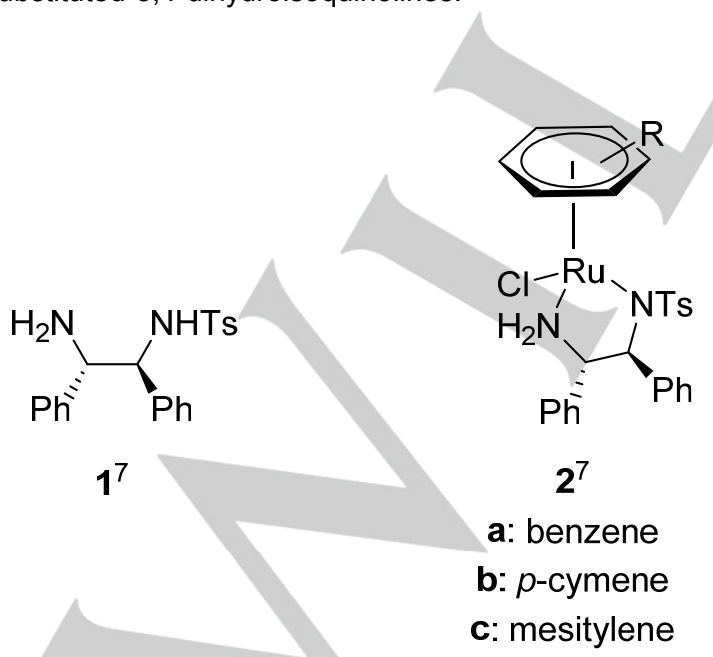

d: hexamethylbenzene
Scalone and Ratovelomanana-Vidal et al. reported the ATH of dihydroisoquinolines $\mathbf{3}$ with the complex $\mathbf{2 a}$ using the formic acid/triethylamine combination as reducing mixture and isopropanol as solvent, so the expected products 4 were obtained with excellent results (Scheme 2$){ }^{8}$<smiles>[R]c1cccc2c1C([Al])=NCC2</smiles>

3

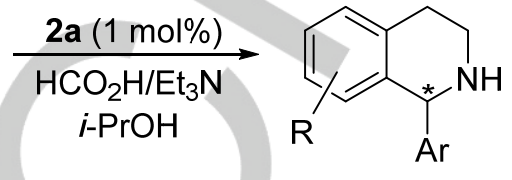

4
$72-97 \%$ yield, $83-99 \%$ ee

$\left[\begin{array}{rl}\mathrm{R}= & \mathrm{H}, 5-\mathrm{MeO}, 6-\mathrm{MeO}, 7-\mathrm{MeO}, 6,7-(\mathrm{MeO})_{2} \\ \mathrm{Ar}= & \mathrm{Ph}, 2-\mathrm{MeC}_{6} \mathrm{H}_{4}, 3-\mathrm{MeC}_{6} \mathrm{H}_{4}, 2,4-\mathrm{Me}_{2} \mathrm{C}_{6} \mathrm{H}_{3}, 2-\mathrm{FC}_{6} \mathrm{H}_{4}, \\ & 4-\mathrm{FC}_{6} \mathrm{H}_{4}, 2-\mathrm{ClC}_{6} \mathrm{H}_{4}, 3-\mathrm{ClC}_{6} \mathrm{H}_{4}, 4-\mathrm{ClC}_{6} \mathrm{H}_{4}, 2-\mathrm{BrC}_{6} \mathrm{H}_{4}, \\ & 3-\mathrm{BrC}_{6} \mathrm{H}_{4}, 2-\mathrm{IC}_{6} \mathrm{H}_{4}, 2-\mathrm{MeOC}_{6} \mathrm{H}_{4}, 4-\mathrm{MeOC}_{6} \mathrm{H}_{4}, \\ & \text { 2,4-(MeO) }{ }_{2} \mathrm{C}_{6} \mathrm{H}_{3}, 1 \text {-naphthyl }\end{array}\right]$

Scheme 2. ATH of dihydroisoquinolines $3^{8}$

High yields (70-94\%) and enantioselectivities (93-99\% ee) were obtained by Liu and co-workers when complex $2 \mathrm{c}$ was used in the ATH of trifluoromethyl aryl $N$-p-methoxyphenyl ketimines with sodium formate as a hydrogen resource and water-dimethylformamide as a cosolvent. ${ }^{9}$ The role of the aromatic ligand in complexes 2 for the reaction shown in Scheme 2 was investigated by Kacer et al. ${ }^{10}$ who also studied the influence of the substituent at the sulfonyl moiety, in complex $\mathbf{2 b}$ and $\mathbf{2 e}, \mathbf{f}^{11}$

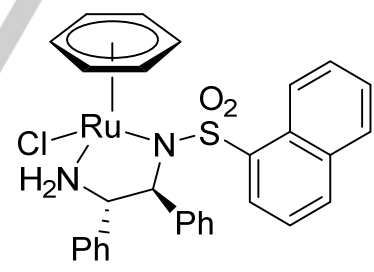

$2 \mathbf{e}^{10,11}$

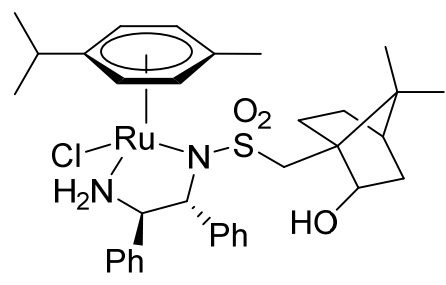

$2 \mathbf{f}^{10,11}$
A theoretical study on the use of complex $\mathbf{2 b}$ in the ATH of different dihydroisoquinoline $\mathbf{3}$ with formic acid and triethylamine was performed by Kacer's group in order to explain the enantioselectivity observed in the process, ${ }^{12}$ including the first report on the systematic parametric investigation on ATH of imines using complexes $2 .{ }^{12 b}$ The same group carried out a DFT study of the ATH of acyclic acetophenone $N$-benzylimine with the complex $\mathbf{2 b}$ and the same reduction mixture, concluding that the configuration of the final amine depends on the configuration of the starting imine: the $(E)$-isomer leads to the $(S)$-amine and the $(Z)$-isomer is reduced to the $(R)$-amine with much lower enantioselectivity. ${ }^{13}$ 
A series of substituted quinolines 5 were subjected to a ATH using the complex 6 and formic acid/triethylamine as the reducing mixture, so the corresponding tetrahydroquinolines 7 were obtained with good conversions but modest enantioselectivities (Scheme 3). ${ }^{14}$<smiles></smiles>

5

\section{$\underset{\mathrm{HCO}_{2} \mathrm{H} / \mathrm{Et}_{3} \mathrm{~N}}{\stackrel{6(0.5 \mathrm{~mol} \%)}{\longrightarrow}}$}<smiles>[R]C1CCc2c#[R]ccc2N1</smiles>

7
$46-95 \%$ conv, $41-73 \%$ ee

$\left[\begin{array}{l}\mathrm{R}^{1}=\mathrm{H}, 6,7-(\mathrm{MeO})_{2} \\ \mathrm{R}^{2}=\mathrm{Me} . \mathrm{Et}, n-\mathrm{Pr}, n-\mathrm{Bu}, \mathrm{Ph}, \mathrm{Ar}\left(\mathrm{CH}_{2}\right)_{2} \\ {\left[\mathrm{Ar}=\mathrm{Ph}, 2-\mathrm{Br}-4,5-\left(\mathrm{OCH}_{2} \mathrm{O}\right) \mathrm{C}_{6} \mathrm{H}_{2}, 3,5-(\mathrm{MeO})_{2} \mathrm{C}_{6} \mathrm{H}_{3}\right]}\end{array}\right]$

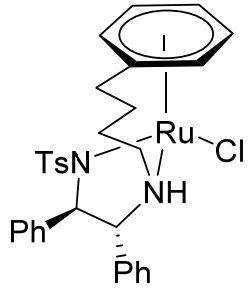

6

Scheme 3. Preparation of compounds $7 .^{14}$

Catalysts 2 ( $1 \mathrm{~mol} \%)$, and other analogues with different substitution at the arene ring, were active in the ATH of different alkylated dihydroisoquinolines 8 and 2-aryl substituted imines $\mathbf{9}$ with formic acid and triethylamine giving the corresponding chiral amines with variable results (13-100\% conv, $21-89 \%$ ee). ${ }^{15}$<smiles>[R]C1=NCCc2cc(OC)c(OC)cc21</smiles>

$\mathbf{8}^{15}$

$[R=M e, E t, B n]$<smiles>[R]c1ccc(C2=NCCCC2)cc1</smiles>

$\left[\mathrm{R}=\mathrm{H}, \mathrm{Me}, \mathrm{F}_{3} \mathrm{C}, \mathrm{MeO}\right]$
A series of $\mathrm{N}$-substituted complexes 10 (1 mol\%) were investigated by Wills et al. for the ATH of the imine 8 with $\mathrm{R}=$ $\mathrm{Me}$ and the formic acid/triethylamine combination. They found that a large alkyl group serves to significantly reduce the activity of the catalyst, however high enantiomeric excesses were still obtained. ${ }^{16}$

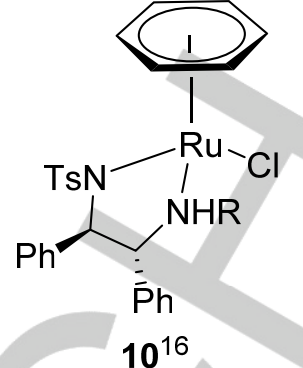

[R = Me, Et, $n$-Pr, $i$-Bu, Bn, $\left.\mathrm{Ph}\left(\mathrm{CH}_{2}\right)_{2}\right]$

The same group has investigated the role of the substitution at the non-tosylated nitrogen in TsDPEN complexes $11-13^{17 a}$ (of type 2), as well as the one with oxygen-containing chain connecting the benzene ring and the non-tosylated nitrogen $14,{ }^{17 b}$ in the ATH of compound 8 with $\mathrm{R}=\mathrm{Me}$, using formic acid and triethylamine as the reducing mixture. In general, conversions were excellent but enantioselectivities were variable.

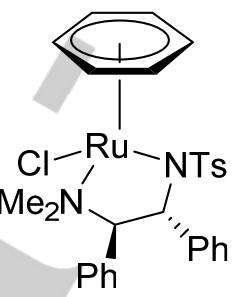

$11^{17 a}$

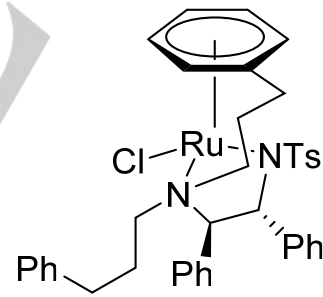

$13^{17 a}$

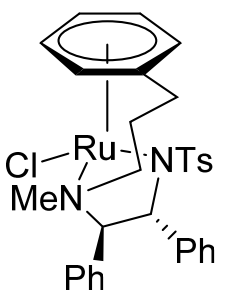

$12^{17 a}$

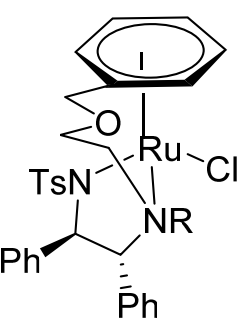

$14^{17 b}$
A series of chiral ruthenium catalysts derived from (+)-limonene 15-21 were prepared by Roszkowski et al. and assayed in the ATH of imines 22-24, and iminium salts 25 and 26, using formic acid and triethylamine. Although conversions are good, enantioselectivities are very variable $(14-100 \%$ conv, $1-95 \%$ ee). ${ }^{18}$ 
<smiles>CC(C)[C@H]1CC[C@@]2(C)[C@H](C1)N[R](Cl)(c1ccccc1)N2[As]</smiles>

$15^{18}$

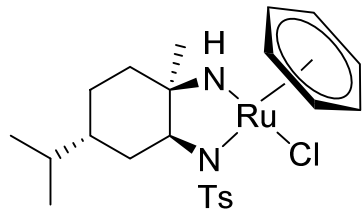

$17^{18}$

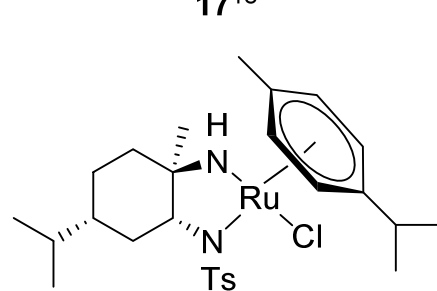<smiles>[Y5]N1N[R](Cl)(C23CC4CC(C2)C(C4)C3)N[C@@]2(C)CC[C@@H](C(C)C)C[C@H]12</smiles>

$19^{18}$<smiles>[Y5]N1[R](Cl)(c2ccccc2)N[C@H]2C[C@@H](C(=C)C)CC[C@@]21C</smiles>

$16^{18}$

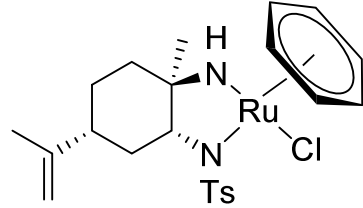

$18^{18}$

$20^{18}$<smiles>[Y5]N1[C@@H]2C[C@@H](C(=C)C)CC[C@@]2(C)N[R]1(Cl)C12CC3CC(CC(C3)C1)C2</smiles>

$21^{18}$<smiles>CC1=NCCC2c3ccccc3NC12</smiles><smiles>O=C1c2ccccc2C(=O)N1CC1=Nc2ccccc2Cn2cccc21</smiles>

$22^{18}$<smiles>O=C1c2ccccc2C(=O)N1CC1=NCCc2ccccc21</smiles>

$24^{18}$<smiles></smiles>

$25^{18}$ $23^{18}$<smiles>COc1cc2c(cc1OC)C1=[N+](CCCC1)CC2</smiles>

$26^{18}$

Ishizuka et al. described the ATH of imines using a complex 27 containing a 'roofed' diamine. Scheme 4 shows an example of

this process for the transformation of the imine $\mathbf{2 8}$ into the amine 29 using the formic acid/triethylamine combination. ${ }^{19}$<smiles>CCOC(=O)N(C)CCO[Mg]</smiles>

28
29

$78 \%$ yield, $90 \%$ ee

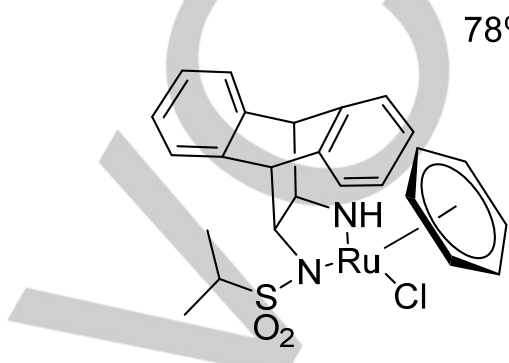

27

Scheme 4. Preparation of the amine $29 .^{19}$

\subsubsection{N-Sulfinyl and N-Phosphinyl Imines as Substrates}

Several 1,2-diamino alcohols were tested for the ATH of $\mathrm{N}$ sulfinyl imines. ${ }^{20}$ From a series of these ligands, the amino indanol derivative $\mathbf{3 0}$ was the most efficient one in the hydrogenation of different sulfinyl imines $\mathbf{3 1}$ with isopropanol under basic conditions, giving, after final deprotection, ${ }^{21}$ the corresponding chiral amines 32 with excellent yields and enantioselectivities (Scheme 5). ${ }^{22}$

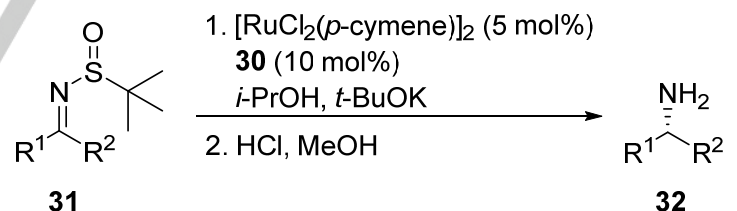

$81-99 \%$ yield, $69->99 \%$ ee $\left[\begin{array}{rl}\mathrm{R}^{1}= & \mathrm{Cy}, \mathrm{Ph}, 4-\mathrm{MeOC}_{6} \mathrm{H}_{4}, 3-\mathrm{ClC}_{6} \mathrm{H}_{4}, 4-\mathrm{ClC}_{6} \mathrm{H}_{4}, 4-\mathrm{F}_{3} \mathrm{CC}_{6} \mathrm{H}_{4}, \\ & 4-\mathrm{O}_{2} \mathrm{NC}_{6} \mathrm{H}_{4}, 4-\mathrm{BocHNC}_{6} \mathrm{H}_{4}, 2 \text {-naphthyl, 2-furyl, 2-thienyl } \\ \mathrm{R}^{2}= & \mathrm{Me}, \mathrm{Et}, n-\mathrm{Pr}, \mathrm{CH}_{2} \mathrm{Cl},(\mathrm{E})-\mathrm{CH}=\mathrm{CHPh}\end{array}\right]$

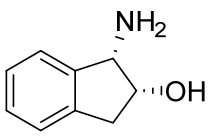

30

Scheme 5. Preparation of amines $32 .^{22}$

An interesting improvement of the former methodology was the substitution of the chiral amino alcohol by an achiral one. From several compounds of this type assayed, the commercially available ligand $\mathbf{3 3}$ was the most active, working not only for aromatic but also for aliphatic ketones, under similar reaction 
conditions. Yields (71-99\%) and enantioselectivities (87->99\% ee) are, in general, excellent. ${ }^{23}$<smiles>CC(C)(N)CO</smiles>

$$
33^{23}
$$

In the former case, a computational study was carried out concluding that the whole process is not concerted, showing that the reaction starts with an interaction between the ruthenium complex and the imine through a N-H-N hydrogen bond. From the first interaction $\mathbf{I}$ and through the most energetic transition state $\mathbf{T S}-\mathrm{I}_{\mathbf{A}}$, an intermediate $\boldsymbol{I I}$ is formed, which then gives a second not so energetic transition state $\mathbf{T S}-\mathrm{I}_{\mathrm{B}}$, that finally produces the final products III as a complex with the ruthenium catalyst (Figure 1). A detailed study of all possible transition states could explain properly the observed diastereoselectivity in the first step of the process. ${ }^{23 b}$

The above mentioned methodology has been successfully applied to the synthesis of nitrogenated saturated heterocycles in a chiral form. Thus, starting from chloro or bromo sulfinyl imines 34, their ATH under the described conditions afforded, after basic treatment, the corresponding heterocycles 35 with excellent yields and diastereoselectivities (Scheme 6). The reaction was not possible for $n=1$, because the starting imine could not be prepared, due to the elimination of hydrogen chloride from the carbonyl precursor under basic conditions. The corresponding desulfinylation of products $\mathbf{3 5}$ under acidic conditions afforded the corresponding deprotected heterocycles in an essentially enantiomerically pure form. ${ }^{24}$
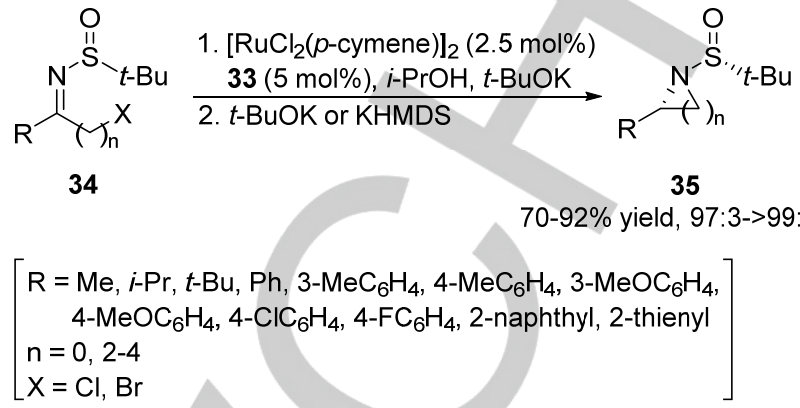

Scheme 6. Preparation of heterocycles $35 .^{24}$

In another simple application of the same methodology, chiral lactams were prepared. The starting $\mathrm{N}$-sulfonyl imino esters 36 (easily prepared from the corresponding keto esters) were submitted to the ATH technology and then to an desulfinylation under acidic conditions to give the lactams 37 through a spontaneous cyclization under the assayed reaction conditions (Scheme 7). As it happened in the chemistry described in Scheme 6 , the change in the configuration of the sulfur atom in the starting $N$-sulfinyl imine gave the opposite configuration in the final product. ${ }^{25}$

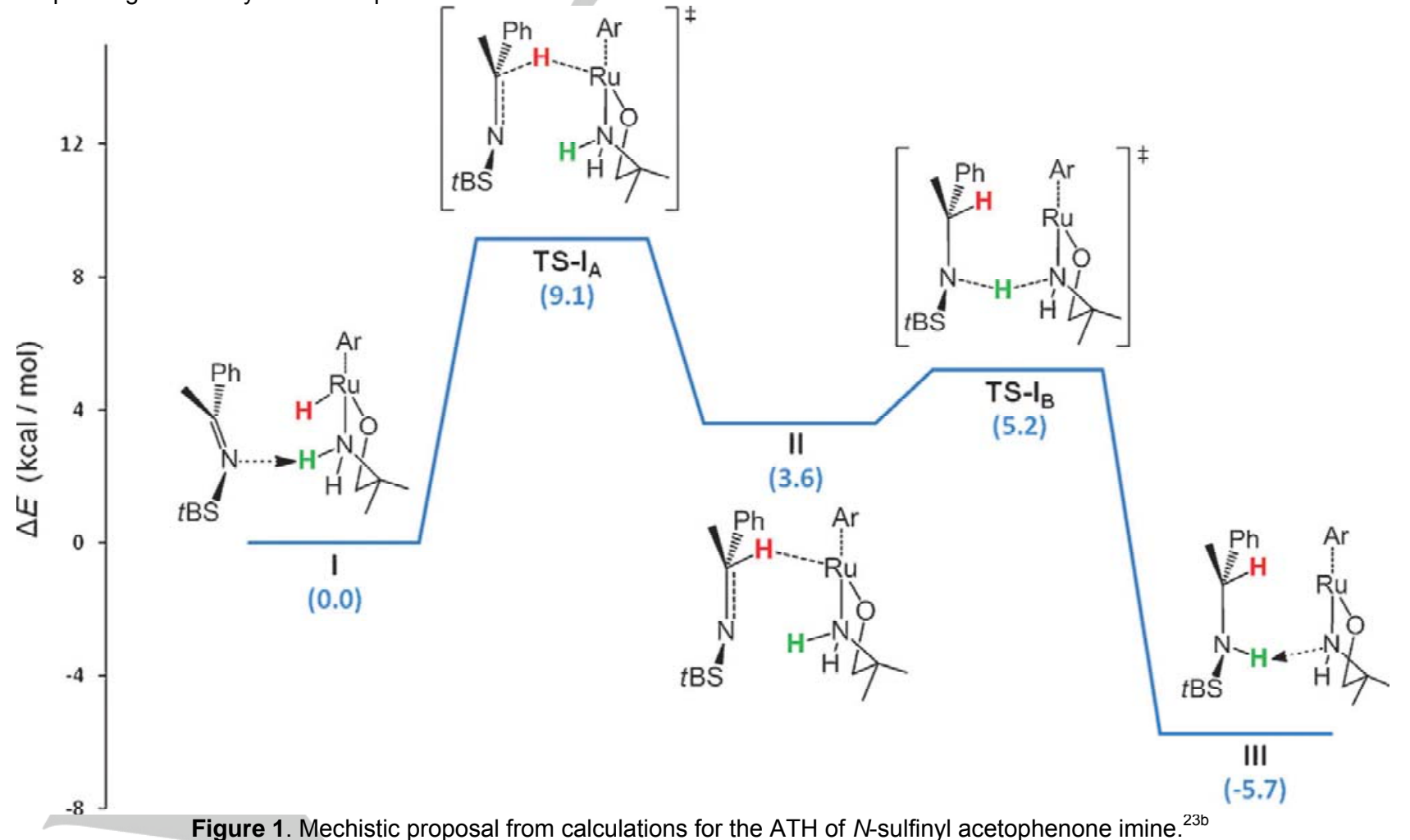




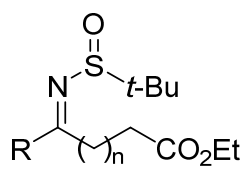

36
1. $\left[\mathrm{RuCl}_{2}(p \text {-cymene })\right]_{2}$

$$
(2.5 \mathrm{~mol} \%)
$$

$$
33(5 \mathrm{~mol} \%)
$$

$i$-PrOH, $t$-BuOK

2. $\mathrm{HCl}, \mathrm{MeOH}$<smiles>[R]C1CCC(=O)N1</smiles>

37

$70-96 \%$ yield, $90->99 \%$ ee
$\left[\begin{array}{l}\mathrm{R}=i-\mathrm{Pr}, c-\mathrm{C}_{5} \mathrm{H}_{9}, c-\mathrm{C}_{6} \mathrm{H}_{11}, 4-\mathrm{MeOC}_{6} \mathrm{H}_{4}, 4-\mathrm{ClC}_{6} \mathrm{H}_{4}, \\ \quad \text { 2-naphthyl, 2-thienyl } \\ \mathrm{n}=1-3\end{array}\right]$

Scheme 7. Preparation of lactams $37 .^{25}$

$\mathrm{N}$-Phosphinyl ketimines $\mathbf{3 8}$ are also suitable starting materials to perform the ATH using the above mentioned ruthenium complex and the chiral ligand $\mathbf{3 0}$, isopropanol under basic conditions being the reducing agent, so protected amines 39 were obtained with good yields and stereoselectivities (Scheme 8). ${ }^{26}$

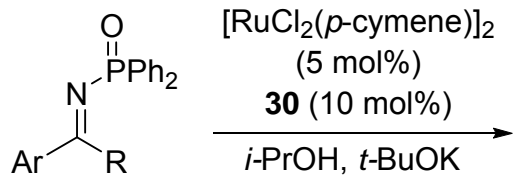

38

$\left[\begin{array}{l}\mathrm{Ar}=\mathrm{Ph}, 4-\mathrm{ClC}_{6} \mathrm{H}_{4} \\ \mathrm{R}=\mathrm{Me}, \mathrm{Et}\end{array}\right]$

Scheme 8. Preparation of phosphinyl amines $39 .^{26}$

\subsubsection{Supported Catalysts}

A catalyst derived from TsDPEN (1) and the ruthenium complex 2b was immobilized in a magnetic siliceous mesocelullar foam material (40). This heterogeneous material afforded high catalytic activity in the ATH of the imine 8 with $\mathrm{R}=\mathrm{Me}$, using formic acid and triethylamine as the reducing mixture. The catalyst showed excellent durability and can be reused conveniently by an external magnet for at least nine times without noticeable loss of enantioselectivity ( $99 \%$ conv, $90-94 \%$ ee). ${ }^{27}$

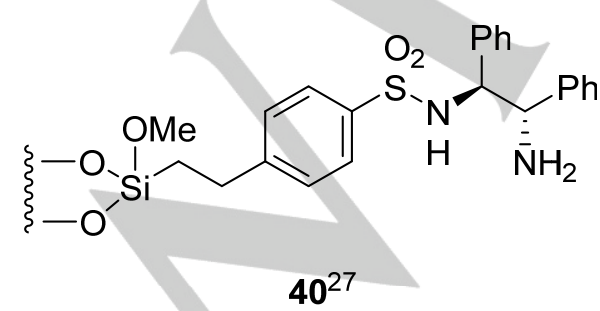

The same methodology but without using magnetite was developed by Liu and Li for the ATH of several substituted 2- methylquinolines of type $\mathbf{5}$, using the preformed complex 41 immobilized in mesoporous silica and the fragment from the complex $\mathbf{2 d}$. The activity of the complex (>99\% conv, $96-99 \%$ ee) was kept after ten catalytic cycles, using in all cases a formic acid/sodium formate buffer aqueous solution $(\mathrm{pH}=5.0){ }^{28}$

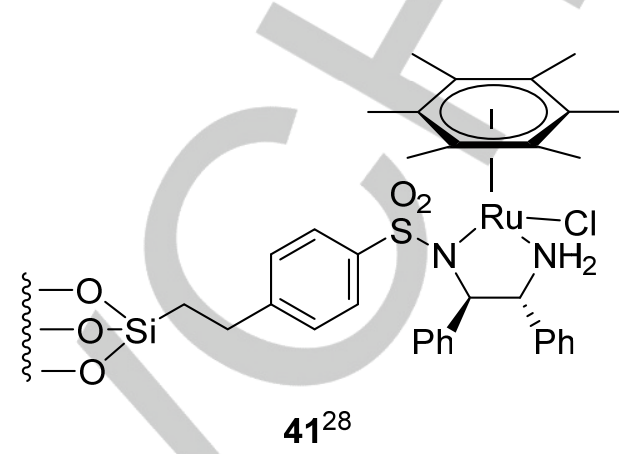

The group of Haraguchi reported the synthesis of several neutral $(42)$ or ionic $(43,44)$ immobilized ligands, which were used in combination with the complex $\mathbf{2 b}$ in the ATH of several imines of type $\mathbf{8}$ with $\mathrm{R}=\mathrm{Me}$ or $\mathbf{2 2}$, as well as compounds $\mathbf{4 5}$ and $\mathbf{2 8}$, with good conversions (86->99\%) and variable enantioselectivities $(64-95 \%$ ee). In all cases, a mixture of formic acid and triethylamine was used for the hydrogenation. ${ }^{29}$

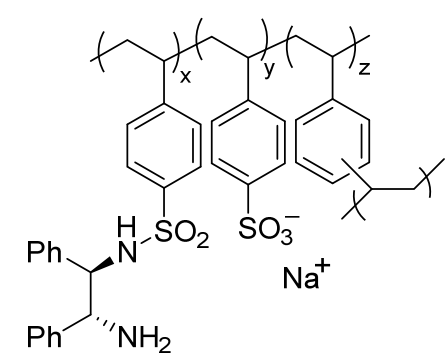

$44^{29}$<smiles>[R]c1ccc(/C(C)=N/Cc2ccccc2)cc1</smiles>

$[\mathrm{R}=\mathrm{H}, \mathrm{Br}]$
The same group used copolymers of type $\mathbf{4 2}$ for the ATH of cyclic sulfonimides $\mathbf{4 6}$ with the ruthenium complex $\mathbf{2 b}$ and aqueous sodium formate as the reducing mixture. Conversions and enantioselectivities were variable, depending on the structure of the copolymeric ligand and the substrate. ${ }^{30}$ 
<smiles></smiles>

$[\mathrm{R}=\mathrm{Me}, t-\mathrm{Bu}, \mathrm{Bn}]$

\subsubsection{Synthetic Applications}

The stereocenter of both enantiomers of tripargine 47 (an alkaloid isolated from the skin of the African racophorid frog) was created by an ATH of the corresponding imine with formic acid and triethylamine catalyzed by both enantiomers of complex $\mathbf{2}$ b. $^{31}$<smiles>N=C(N)NCCC[C]1NCCc2c1[nH]c1ccccc21</smiles>

$47^{31}$

The same reaction condition, concerning catalyst and hydrogen source, were used for the stereoselective synthesis of norephedrine (48) and norpseudoephedrine (49) (two members of the amphetamine family of Ephedra alkaloids with synpathomimetic psychoactivity), the key step being the ATH of the racemic sulfamidate imine $\mathbf{5 0} .^{32}$<smiles>CC(N)C(O)c1ccccc1</smiles>

$48^{32}$<smiles>CNC(C)C(O)c1ccccc1</smiles>

$49^{32}$<smiles>CC1=NOS(=O)OC1c1ccccc1</smiles>

$50^{32}$
Also the same combination of reagents and conditions were applied to generate the stereocenter at the $\mathrm{C}-1$ in the $\beta$ carboline alkaloid eudistomidin G (51) (isolated from marine tunicates of the genus Eudistoma) by an ATH of the corresponding imine. ${ }^{33}$

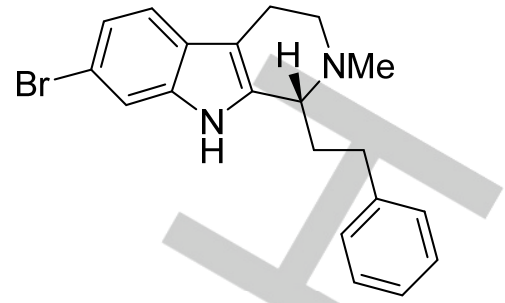

$51^{33}$

\subsection{Rhodium Catalysts}

Rhodium catalysts $\mathbf{5 2}$ and $\mathbf{5 3}$ have shown to be very actyive in the ATH of different cyclic and acyclic imines of type 5, 8, 22, 46 and 54 using the formic acid/triethylamine combination as the reducing mixture. Conversions and enantioselectivities were variable in all cases. . $^{14,34}$

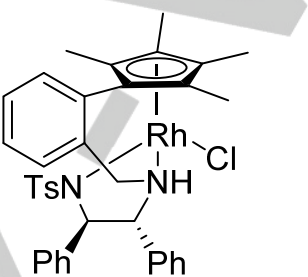

$$
\mathbf{5 2}^{14,34}(0.5 \mathrm{~mol} \%)
$$$$
\mathrm{HCO}_{2} \mathrm{H} / \mathrm{Et}_{3} \mathrm{~N}
$$

$16-100 \%$ conv, $69-94 \%$<smiles>[R]c1ccc2ccccc2n1</smiles>

$\mathrm{R}=\mathrm{Et}, n-\mathrm{Pr}, n-\mathrm{Bu}, t-\mathrm{Bu}, \mathrm{Ph}$, $\mathrm{Ph}\left(\mathrm{CH}_{2}\right)_{2}, \mathrm{CO}_{2} \mathrm{Me}$, $\left(\mathrm{CH}_{2}\right)_{2}\left[2-\mathrm{Br}-4,5-\left(\mathrm{OCH}_{2} \mathrm{O}\right)\right] \mathrm{C}_{6} \mathrm{H}_{2}$, $\left(\mathrm{CH}_{2}\right)_{2}\left[3,5-(\mathrm{MeO})_{2} \mathrm{C}_{6} \mathrm{H}_{3}\right.$

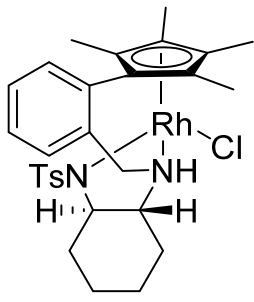

$53^{14,34}(0.5 \mathrm{~mol} \%)$

$\mathrm{HCO}_{2} \mathrm{H} / \mathrm{Et}_{3} \mathrm{~N}$

$16-100 \%$ conv, $8-79 \%$ ee<smiles>COc1cc2c(cc1OC)C(C)=NCC2</smiles>
$8^{14,34}$<smiles>[R]C1=NCCc2c1[nH]c1ccccc21</smiles>

$\mathbf{2 2}^{14,34}$

$[\mathrm{R}=\mathrm{Me}, \mathrm{Ph}]$<smiles>Cc1n[s+]([O-])c2ccccc12</smiles>

$46^{14,34}$<smiles>C/C(=N\Cc1ccccc1)c1ccccc1</smiles>

$54^{14,34}$
Xiao et al. investigated the influence of the substituent at the sulfonyl moiety in the monosubstituted chiral diamine 55, finding that the best results were obtained for the 4-tert-butylphenyl group. Thus, the corresponding complex $\mathbf{5 6}$ was efficiently used in the ATH of a large series of substituted quinolines $\mathbf{5 7}$ with 
sodium formate in buffered water to yield the corresponding tetrahydro derivatives 58, with excellent yields and enantioselectivities (Scheme 9). ${ }^{35}$

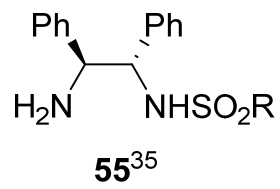

[ $\mathrm{R}=\mathrm{Me}, 4-\mathrm{MeC}_{6} \mathrm{H}_{4}, \mathrm{Me}_{5} \mathrm{C}_{6}, 2,4,6-i-\mathrm{Pr}_{3} \mathrm{C}_{6} \mathrm{H}_{2}, 4-t-\mathrm{BuC}_{6} \mathrm{H}_{4}$, 4- $\mathrm{F}_{3} \mathrm{CC}_{6} \mathrm{H}_{4}, 3,5-\left(\mathrm{F}_{3} \mathrm{C}\right)_{2} \mathrm{C}_{6} \mathrm{H}_{3}$, 1-naphthyl, camphor .
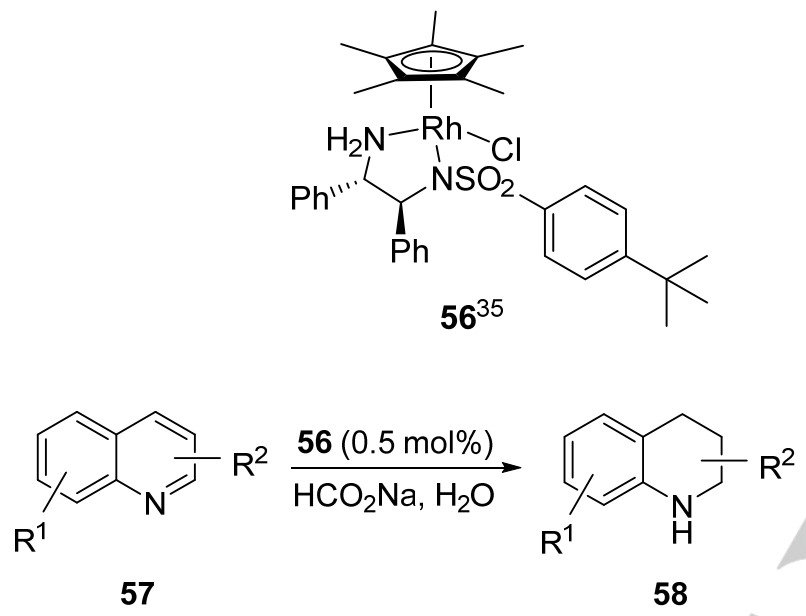

$80-97 \%$ yield, $86-98 \%$ ee

Scheme 9. Tetrahydroquinolines $\mathbf{5 8}$ prepared by $\mathrm{ATH}^{35}$

Among the wide number of compounds $\mathbf{5 8}$ prepared, three bioactive alkaloids, namely (+)-galipinine (59), (-)-angustureine (60) and (S)-flumequine (61) were synthesized using this methodology.<smiles>CN1c2ccccc2CC[C@@H]1CCc1ccc2c(c1)OCO2</smiles>

59

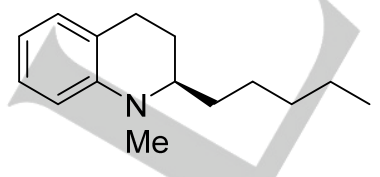

60<smiles>C[C@H]1CCc2cc(F)cc3c(=O)c(C(=O)O)cn1c23</smiles>

From the family of ligands 55 , the one having $\mathrm{R}=4-\mathrm{MeC}_{6} \mathrm{H}_{4}$ (55a) showed to be the most efficient in the rhodium-catalyzed ATH of different $\mathrm{N}$-sulfonyl imines $\mathbf{6 2}$ in aqueous sodium formate, yielding the expected chiral tosyl amines 63 , in general, with excellent results in terms of chemical yield and enantioselectivity (Scheme 10). Yields were improved slightly by addition of 10 mol\% of Triton $\mathrm{X}-100$. Other imines 64 a-d behave also in the same way for the same process.

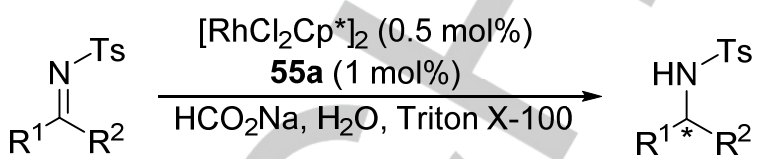

62
63

$12.7-99.1 \%$ yield 90.4-98.0\% ee<smiles>CC(C)(C)c1nsc2ccccc12</smiles>

$64 a$

$89.2 \%$ yield, $70.8 \%$ ee<smiles>O=S(=O)(O[Mg][Mg])c1ccccc1</smiles><smiles>CC(=N)c1cccc2ccccc12</smiles>

$64 \mathrm{c}$

$60.0 \%$ yield, $86 \%$ ee<smiles>C/C(=N/[S-](=O)[O-])C(C)(C)C</smiles>

$64 b$
$93.8 \%$ yield, $96.7 \%$ ee<smiles>COc1ccc(S(=O)/N=C(\C)c2ccccc2)cc1</smiles>

64d

$99.1 \%$ yield, $95.7 \%$ ee

Scheme 10. ATH of sulfonyl imines 62 and $64 .^{36}$

An enantioselective synthesis of cyclic sulfamidates 66 was performed by a rhodium-catalyzed ATH of the imine derivatives 65, using the well-defined chiral complex 67 (of type 56), and the formic acid/triethylamine combination as the hydrogenation source (Scheme 11). ${ }^{37}$ 
$\stackrel{\mathrm{N}-\mathrm{SO}_{2}}{\stackrel{67(0.5 \mathrm{~mol} \%)}{\mathrm{O}}}$

65<smiles></smiles>

66
$91-99 \%$ yield, $16-99 \%$ ee

$\mathrm{R}=n-\mathrm{C}_{6} \mathrm{H}_{13}, \mathrm{Ph}, 2-\mathrm{MeC}_{6} \mathrm{H}_{4}, 3-\mathrm{MeC}_{6} \mathrm{H}_{4}, 4-\mathrm{MeC}_{6} \mathrm{H}_{4}$, 2- $\mathrm{MeOC}_{6} \mathrm{H}_{4}, 3-\mathrm{MeOC}_{6} \mathrm{H}_{4}, 4-\mathrm{MeOC}_{6} \mathrm{H}_{4}, 2-\mathrm{ClC}_{6} \mathrm{H}_{4}$, $3-\mathrm{ClC}_{6} \mathrm{H}_{4}, 4-\mathrm{ClC}_{6} \mathrm{H}_{4}, 4-\mathrm{FC}_{6} \mathrm{H}_{4}, 4-\mathrm{NCC}_{6} \mathrm{H}_{4}$, $4-\mathrm{MeO}_{2} \mathrm{CC}_{6} \mathrm{H}_{4}, 4-\mathrm{O}_{2} \mathrm{NC}_{6} \mathrm{H}_{4}$

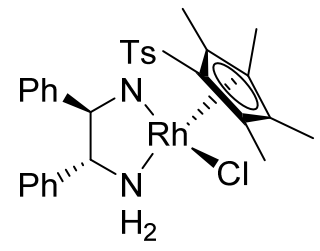

67

Scheme 11. Preparation of sulfamidates $66 .^{37}$

The same catalyst 67 was satisfactorily used in the dynamic kinetic resolution (DKR) of racemic substituted sulfamidates 68 (of type 65), through an ATH with formic acid and triethylamine, so the corresponding products 69 were obtained with high yield, as well as diastereo- and enantioselectivity (Scheme 12). ${ }^{38}$<smiles>[R]C1=NS(=O)(=O)OC1COCC</smiles>

68

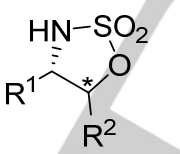

69
$94-99 \%$ yield, $22-99 \%$ ee $>20: 1 \mathrm{dr}$

$\mathrm{R}^{1}=\mathrm{Ph}, 2-\mathrm{ClC}_{6} \mathrm{H}_{4}, 3-\mathrm{ClC}_{6} \mathrm{H}_{4}, 4-\mathrm{ClC}_{6} \mathrm{H}_{4}, 4-\mathrm{FC}_{6} \mathrm{H}_{4}, 4-\mathrm{F}_{3} \mathrm{CC}_{6} \mathrm{H}_{4}$, $3-\mathrm{MeOC}_{6} \mathrm{H}_{4}, 4-\mathrm{MeOC}_{6} \mathrm{H}_{4}, 3-\mathrm{MeC}_{6} \mathrm{H}_{4}, 4-\mathrm{MeC}_{6} \mathrm{H}_{4}$ $\mathrm{R}^{2}=\mathrm{Ph}, 2-\mathrm{ClC}_{6} \mathrm{H}_{4}, 3-\mathrm{ClC}_{6} \mathrm{H}_{4}, 4-\mathrm{ClC}_{6} \mathrm{H}_{4}, 4-\mathrm{FC}_{6} \mathrm{H}_{4}, 4-\mathrm{F}_{3} \mathrm{CC}_{6} \mathrm{H}_{4}$, $3-\mathrm{MeOC}_{6} \mathrm{H}_{4}, 4-\mathrm{MeOC}_{6} \mathrm{H}_{4}, 3-\mathrm{MeC}_{6} \mathrm{H}_{4}, 4-\mathrm{MeC}_{6} \mathrm{H}_{4}$

Scheme 12. Preparation of compounds 69 by an $\mathrm{ATH},{ }^{38}$

A variant of the methodology showed in Scheme 12 was applied to the ester derivatives $\mathbf{7 0}$, which under the same reaction conditions and with the same catalyst afforded the expected products 71 with excellent results (Scheme 13). ${ }^{39}$

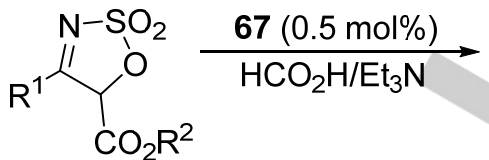

70

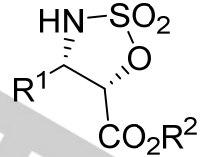

71

$20->99 \%$ conv, $47->99 \%$ ee $>25: 1 \mathrm{dr}$

$\left[\begin{array}{rl}\mathrm{R}^{1}= & \mathrm{Ph}, 2-\mathrm{MeC}_{6} \mathrm{H}_{4}, 3-\mathrm{MeC}_{6} \mathrm{H}_{4}, 4-\mathrm{MeC}_{6} \mathrm{H}_{4}, 3-\mathrm{ClC}_{6} \mathrm{H}_{4}, \\ & \text { 4- } \mathrm{ClC}_{6} \mathrm{H}_{4}, 4-\mathrm{FC}_{6} \mathrm{H}_{4}, 4-\mathrm{F}_{3} \mathrm{CC}_{6} \mathrm{H}_{4}, 4-\mathrm{MeOC}_{6} \mathrm{H}_{4}, \\ & \text { 4- } \mathrm{NCC}_{6} \mathrm{H}_{4}, 4-\mathrm{MeO}_{2} \mathrm{CC}_{6} \mathrm{H}_{4}, \text { 2-naphthyl, 2-furyl, } \\ & \text { 2-thienyl, } n-\mathrm{Pr}, \mathrm{Ph}\left(\mathrm{CH}_{2}\right)_{2}, c-\mathrm{C}_{6} \mathrm{H}_{11} \\ \mathrm{R}^{2}= & \mathrm{Me}, i-\mathrm{Pr}, t-\mathrm{Bu}, \mathrm{Bn}\end{array}\right]$

Scheme 13. Compounds 71 obtained by an ATH. ${ }^{39}$

Several substituted dihydroisoquinolines 8 were submitted to an ATH with aqueous sodium formate to give compounds $\mathbf{7 2}$, the catalyst $\mathbf{6 7}$ being in situ generated by mixing the corresponding rhodium complex $\left[\mathrm{RhCl}_{2} \mathrm{Cp}^{*}\right]_{2}$ and the monosulfonated diamine 1. Results were variable depending on the structure of the starting material, and the role of the cosolvent was analized by DFT calculations (Scheme 14). ${ }^{40}$<smiles>[R]C1=NCCc2cc(OC)c(OC)cc21</smiles>

8
$\left[\mathrm{RhCl}_{2} \mathrm{Cp}^{*}\right]_{2}$ $\underset{(0.5 \mathrm{~mol} \%)}{1(1.5 \mathrm{~mol} \%)}$
$\underset{\mathrm{HCO}_{2} \mathrm{Na}}{\mathrm{H}_{2} \mathrm{O}, \mathrm{MeOH}}$<smiles>[R]C1NCCc2cc(OC)c(OC)cc21</smiles>

72

$15-97 \%$ yield, $14-99 \%$ ee
Scheme 14. Preparation of compounds $72 .^{40}$

\subsection{Iron Catalysts}

Morris et al. used extensively the complexes $\mathbf{7 3}$ and $\mathbf{7 4}$ in the ATH of different ketimines. Thus, phosphinoyl imines 75 were easily transformed into the corresponding chiral protected amines 76, using isopropanol under basic conditions (Scheme $15) .^{41}$ 


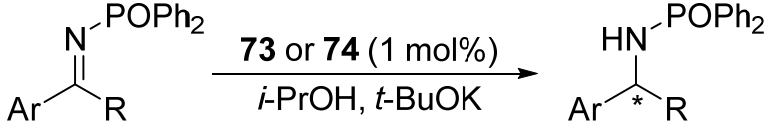

75

76

$40-92 \%$ conv, $95->99 \%$ ee

$\mathrm{Ar}=\mathrm{Ph}, 4-\mathrm{MeC}_{6} \mathrm{H}_{4}, 3-\mathrm{MeOC}_{6} \mathrm{H}_{4}, 4-\mathrm{MeOC}_{6} \mathrm{H}_{4}$, 4- $\mathrm{BrC}_{6} \mathrm{H}_{4}$, 2-naphthyl, 2-thienyl, 5-Cl-2-thienyl $\mathrm{R}=\mathrm{Me}, \mathrm{Et} ; \mathrm{Ar}-\mathrm{R}=2-\left(\mathrm{CH}_{2}\right)_{\mathrm{n}} \mathrm{C}_{6} \mathrm{H}_{4}[\mathrm{n}=2,3]$<smiles>O=C1N(c2ccccc2)P(c2ccccc2)P(c2ccccc2)C2(Pc3ccccc3)N1CCCP2c1ccccc1</smiles>

73

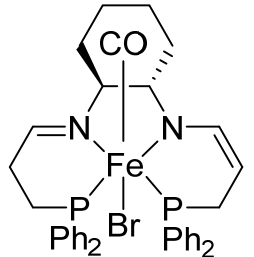

74
Scheme 15. Iron-catalyzed ATH of imines $75 .^{41}$

The same type of substrates 75 , even having two aliphatic groups $(\mathrm{Ar}=\mathrm{alkyl})$, have been submitted to an ATH using a mixture of the ligand 77 and the complex $\left[\mathrm{Et}_{3} \mathrm{NH}\right]\left[\mathrm{HFe}_{3}(\mathrm{CO})_{11}\right]$ with isopropanol and potassium hydroxide as the reaction medium, giving very good yields (67-95\%) and excellent enantioselectivities $(89-98 \%$ ee), except for fully aliphatic systems $\left(35-62 \%\right.$ yield and $29-39 \%$ ee). ${ }^{42}$

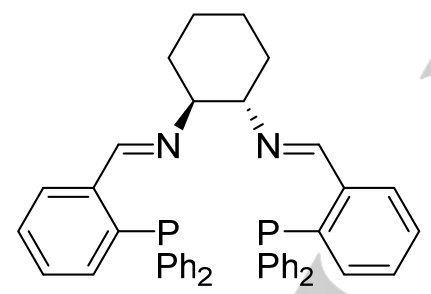

$77^{42}$

\section{Organocatalyzed Reactions}

Most of the organocatalyzed ATH reactions of imines use a chiral BINOL-derived phosphoric acid $\mathbf{7 8}$ as the catalyst and a Hantzsch ester $\mathbf{7 9}$ as the hydrogen source. Although turnover frequencies of organocatalytic imine hydrogenations are still lower than those of metal-catalyzed processes, there are some advantages concerning mild and environmentally friendly conditions, as well as excellent selectivities. ${ }^{43,44}$<smiles>[R]c1cc2ccccc2c(-c2c(OP(=O)(O)O)c([R])cc3ccccc23)c1OP</smiles>

$78^{42,43}$<smiles>[R]OC(=O)C1=C(C)NC(C([R20])=O)=C(C)C1</smiles>

$79^{42,43}$
Rueping proposed a general mechanism for the ATH of imines with the 78/79 combination that involves the protonation of the imine followed by a hydrogen transfer from the Hantzsch ester (Scheme 16). ${ }^{45}$<smiles>[R]OC(=O)C1=C(C)NC(C)=C(C([R20])=O)C1</smiles>

Scheme 16. Proposed mechanism for the organocatalyzed ATH of imines. ${ }^{45}$

Enamines 80 were transformed into the corresponding chiral amines 81 by using a mixture of the phosphoric acid 78 with $\mathrm{R}=$ 9-anthryl and 79 with $\mathrm{R}=\mathrm{Et}$, in the presence of a catalytic amount of acetic acid. The participation of a protonated intermediate 82 has been proposed (Scheme 17). ${ }^{46}$

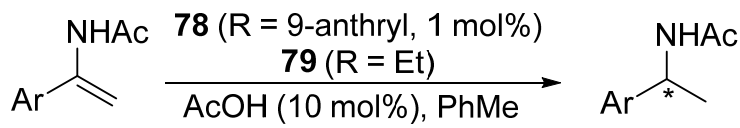

80

81

$31-99 \%$ yield, $41-95 \%$ ee

$\left[\begin{array}{rl}\mathrm{Ar}= & \mathrm{Ph}, 4-\mathrm{MeC}_{6} \mathrm{H}_{4}, 4-\mathrm{ClC}_{6} \mathrm{H}_{4}, 4-\mathrm{FC}_{6} \mathrm{H}_{4}, 4-\mathrm{F}_{3} \mathrm{CC}_{6} \mathrm{H}_{4}, \\ & \text { 4-MeOC } \mathrm{H}_{4} \mathrm{H}_{4}, 1-\text { naphthyl, 2-naphthyl, 3- } \mathrm{MeOC}_{6} \mathrm{H}_{4}, \\ & \text { 2-MeOC } \mathrm{H}_{6} \mathrm{H}_{4}\end{array}\right]$<smiles>C=[N+]=C(C)[Al]</smiles>

Scheme 17. ATH of enamines $80^{46}$ 
The same combination of the acid 78 with $\mathrm{R}=9$-anthryl, and 79 with $\mathrm{R}=\mathrm{Et}$, was used for the ATH of protected alkynyl imines 83, to give chiral vinyl amino esters $\mathbf{8 4}$, in which both the triple bond and the $\mathrm{C}=\mathrm{N}$ one are reduced in one only step (Scheme 18). ${ }^{47}$

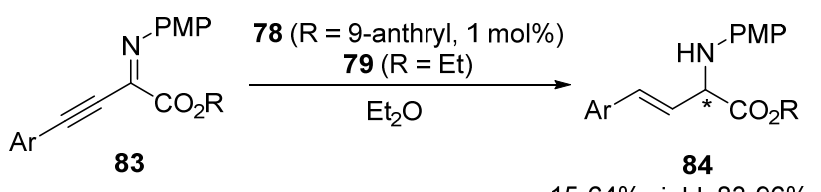

$15-64 \%$ yield, $83-96 \%$ ee

Ar = Ph, 4- $-\mathrm{MeC}_{6} \mathrm{H}_{4}, 3-\mathrm{MeC}_{6} \mathrm{H}_{4}, 4-\mathrm{ClC}_{6} \mathrm{H}_{4}, 3-\mathrm{FC}_{6} \mathrm{H}_{4}$, 1-naphthyl $]$ $\mathrm{R}=\mathrm{Me}, \mathrm{Et}, i-\operatorname{Pr}, t-\mathrm{Bu}$

\section{Scheme 18. Preparation of chiral allyl amines $\mathbf{8 4}{ }^{47}$}

In the case of starting from ketimines 85 the organocatalyzed ATH was carried out with a silylated phosphoric acid 78 with $\mathrm{R}=$ $\mathrm{Ph}_{3} \mathrm{Si}$ and a tert-butyl Hantzsch ester (79 with $\mathrm{R}=t-\mathrm{Bu}$ ), so the corresponding chiral amines $\mathbf{8 6}$ were obtained in high yield and enantioselectivity (Scheme 19). ${ }^{48}$
The same group reported the ATH of 3-substituted quinolines 89, finding that the best reaction conditions were the use of the phosphoric acid 90 and the hydrogen donor 79 with $\mathrm{R}=i$-Pr. The full hydrogenation of the heterocyclic ring led to the formation of the chiral tetrahydroquinolines 91 , with variable yields and very good enantioselectivities (Scheme 21). ${ }^{50 a}$ The same protocol was applied to 4-substituted quinolines with similar results. ${ }^{50 b}$

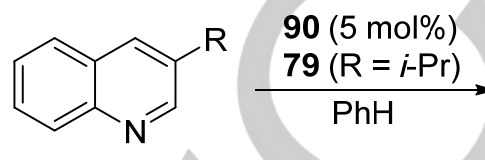

89<smiles>[R]c1ccc(O)c(C([R])N)c1</smiles>

86 $56-99 \%$ yield, $81-99 \%$ ee

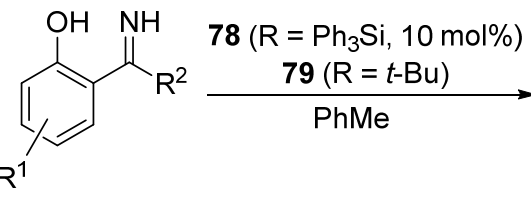

85

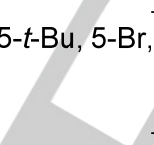
$5-\mathrm{MeO}, 5-\mathrm{O}_{2} \mathrm{~N}, 6-\mathrm{EtO}$

$\mathrm{R}^{2}=\mathrm{Me}, \mathrm{Et}, n-\mathrm{Pr}, n-\mathrm{C}_{6} \mathrm{H}_{13}, i-\mathrm{Pr}$

Scheme 19. Preparation of amines 86 by an $\mathrm{ATH}^{48}$

Rueping et al. have studied the ATH of different nitrogencontaining heterocycles. Thus, $3 \mathrm{H}$-indoles $\mathbf{8 7}$ were treated with the Brønsted acid 78 with $\mathrm{R}=9$-anthryl, and 79 with $\mathrm{R}=\mathrm{Et}$, to afford the corresponding indolines $\mathbf{8 8}$, with excellent yields and enantioselectivities (Scheme 20). ${ }^{49}$

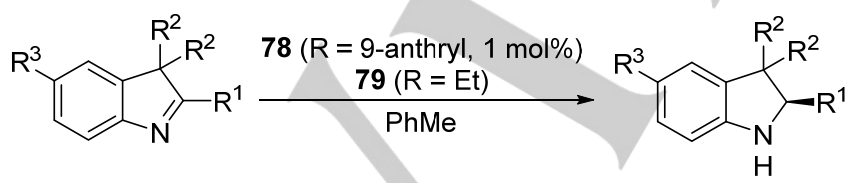

87

88

$84-99 \%$ yield $96->99 \%$ ee

$\mathrm{R}^{1}=\mathrm{Ph}, 4-\mathrm{BrC}_{6} \mathrm{H}_{4}, 4-\mathrm{FC}_{6} \mathrm{H}_{4}, 4-\mathrm{F}_{3} \mathrm{CC}_{6} \mathrm{H}_{4}, 4-\mathrm{MeOC}_{6} \mathrm{H}_{4}$, 2-naphthyl $\mathrm{R}^{2}=\mathrm{Me} ; \mathrm{R}_{2}-\mathrm{R}_{2}=\left(\mathrm{CH}_{2}\right)_{4},\left(\mathrm{CH}_{2}\right)_{5}$ $\mathrm{R}^{3}=\mathrm{H}, \mathrm{F}, \mathrm{MeO}$

Scheme 20. Preparation of indolines 88 by an $A T H .{ }^{49}$
Scheme 21. Preparation of tetrahydroquinolines 91 by an ATH. ${ }^{50 a}$

For the ATH of 2-substituted quinolines 92 (of type 5), the best results were obtained with phosphoric acid 78 with $R=2,4,6-i-$ $\mathrm{Pr}_{3} \mathrm{C}_{6} \mathrm{H}_{2}$ and the Hantzsch ester 79 with $\mathrm{R}=t-\mathrm{Bu}$, the process being carried out under aqueous conditions, to give the corresponding 2-substituted tetrahydroquinolines 93 , in general with excellent results (Scheme 22). ${ }^{51}$<smiles>Fc1ccc2ccccc2n1</smiles>

92<smiles>[R]C1CCc2ccccc2N1</smiles>

$60-95 \%$ yield $83-97 \%$ ee

\footnotetext{
$\mathrm{R}=\mathrm{Ph}, 3-\mathrm{FC}_{6} \mathrm{H}_{4}, 3-\mathrm{MeC}_{6} \mathrm{H}_{4}, 4-\mathrm{EtC}_{6} \mathrm{H}_{4}, 3-\mathrm{BrC}_{6} \mathrm{H}_{4}, 4-\mathrm{F}_{3} \mathrm{CC}_{6} \mathrm{H}_{4}$, 4- $\mathrm{MeOC}_{6} \mathrm{H}_{4}, 4-\mathrm{ClC}_{6} \mathrm{H}_{4}, 4-\mathrm{FC}_{6} \mathrm{H}_{4}, 3-\mathrm{MeOC}_{6} \mathrm{H}_{4}$ 3,4,5-(MeO) ${ }_{3} \mathrm{C}_{6} \mathrm{H}_{2}$, 2-naphthyl, 1,1'-biphenyl-4-yl, 2-furyl
}

Scheme 22. Preparation of compounds 93 by an ATH. ${ }^{51}$

Other heterocycles subjected to an ATH were 2-substituted quinoxalines 94 , which by reaction with the phosphoric acid 78 
with $\mathrm{R}=9$-anthryl and 79 with $\mathrm{R}=\mathrm{Et}$ in chloroform, gave the expected tetrahydro derivatives 95 with excellent yields and enantioselectivities (Scheme 23). ${ }^{52}$ The same conditions were applied to 2-substituted quinoxalin-3-ones with variable yields (42-75\%) and excellent enantioselectivities (92-98\% ee).<smiles>[R]c1ccc2ncc([R])nc2c1</smiles>
94

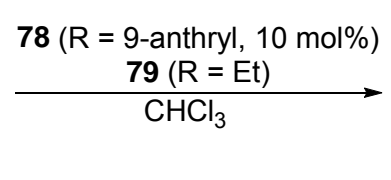

$\mathrm{R}^{1}$

(2)

$73-98 \%$ yield $90-98 \%$ ee

$$
\left[\begin{array}{c}
\mathrm{R}^{1}=\mathrm{H}, 6-\mathrm{Br}, 7-\mathrm{Br}, 6-\mathrm{Cl}, 7-\mathrm{Cl}, 6,7-\mathrm{Cl}_{2} \\
\mathrm{R}^{2}=\mathrm{Ph}, 4-\mathrm{MeC}_{6} \mathrm{H}_{4}, 4-\mathrm{BrC}_{6} \mathrm{H}_{4}, 4-\mathrm{MeOC}_{6} \mathrm{H}_{4}, 3-\mathrm{BrC}_{6} \mathrm{H}_{4} \\
\quad \text { 3,4- } \mathrm{Cl}_{2} \mathrm{C}_{6} \mathrm{H}_{3}, 2 \text { 2-naphthyl, 2-furyl, 2-thienyl }
\end{array}\right]
$$

Scheme 23. Preparation of compounds 95 by an ATH. ${ }^{52}$

Finally, Rueping's group reported the ATH of substituted 1,5benzodiazepinones $\mathbf{9 6}$ using the Hantzsch ester $\mathbf{7 9}$ with $\mathrm{R}=$ allyl and the phosphoric acid amide 97 in tert-butyl methyl ether (MTBE), so the corresponding products 98 were isolated as the acyl derivatives with variable yields but excellent enantioselectivities (Scheme 24). ${ }^{53}$<smiles>[R][R]1cccc2c1N=C(c1ccc([R])cc1)CC(=O)N2</smiles>

96

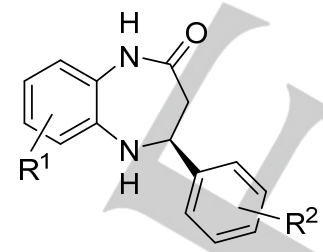

98

$$
51-98 \% \text { yield }
$$$$
83-99 \% \text { ee }
$$

$\left[\mathrm{R}^{1}=\mathrm{H}, 7-\mathrm{Me}, 8-\mathrm{Me}, 7-\mathrm{Br}, 7-\mathrm{Cl}, 8-\mathrm{Br}, 8-\mathrm{Cl}, 7,8-\mathrm{Cl}_{2}\right]$ $\mathrm{R}^{2}=\mathrm{H}, 2-\mathrm{F}, 4-\mathrm{O}_{2} \mathrm{~N}, 3,4-(\mathrm{MeO})_{2}$

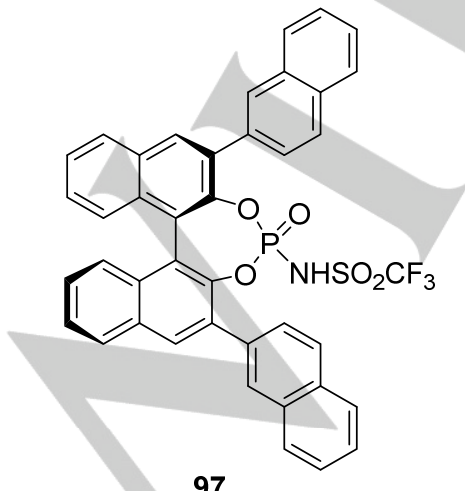

97
A little bit more sophisticated is the double axially chiral phosphoric acid 98 , which was successfully used $(0.2 \mathrm{~mol} \%)$ in combination with the hydrogen donor 79 with $\mathrm{R}=$ tert-Butyl, for the transformation of 92 into 93 (Scheme 22) in diethyl ether. Results were excellent in terms of yield (normally >99\%) and enantioselectivity $\left(88-98 \%\right.$ ee).$^{54}$

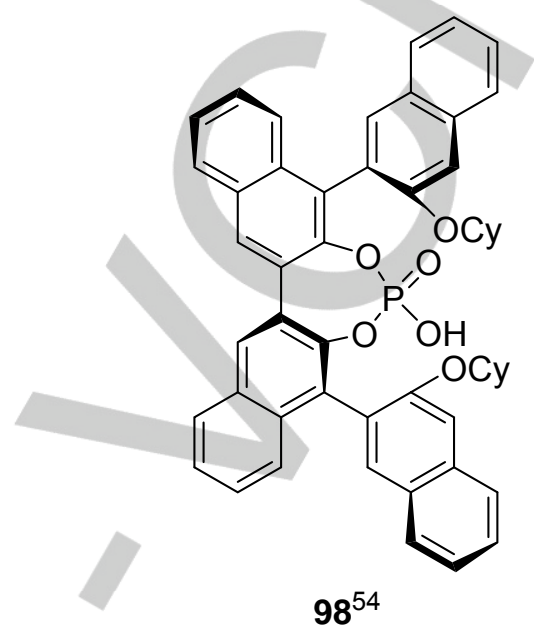

Metallinos et al. conducted the ATH of substituted 1,10phenantrolines 99 with the two phosphoric acids 78 with $R=2$ naphthyl and 9-phenanthryl, and the hydrogen donor 79 with $\mathrm{R}=$ $\mathrm{Et}$, in benzene, to give the corresponding octahydro derivatives 100 , with variable yields and enantioselectivities (Scheme 25). ${ }^{55}$<smiles>[R]c1ccc2ccc3ccc(C)nc3c2n1</smiles>

$78(R=2-$ naphthyl, 9-phenanthryl, $2 \mathrm{~mol} \%)$ $79(\mathrm{R}=\mathrm{Et})$ $\mathrm{PhH}$ 100 $11-88 \%$ yield $25-99 \%$ ee $\mathrm{R}^{2}$<smiles>[R]C1CCc2ccc3c(c2N1)NC([R])CC3</smiles>

$$
\left[\begin{array}{l}
\mathrm{R}^{1}=\mathrm{Me}, n-\mathrm{Bu}, i-\mathrm{Pr}, \mathrm{Ph}, \mathrm{AcNHCH}_{2} \\
\mathrm{R}^{2}=\mathrm{H}, \mathrm{Me}, n-\mathrm{Bu}, \mathrm{Ph}
\end{array}\right]
$$

Scheme 25. Preparation of compounds 100 by an $\mathrm{ATH}^{55}$

An interesting variant of the ATH using a chiral phosphoric acid was the use of polymers 101 and 102 prepared by radical copolymerization of the vinyl derivatives 103 and 104, respectively, with styrene and divinylbenzene. This way of heterogenizating of the catalyst allows the ATH of 2-substituted quinolines 92 and benzoxazine 105 (to give 106) with excellent results even after twelve cycles. ${ }^{56}$ 


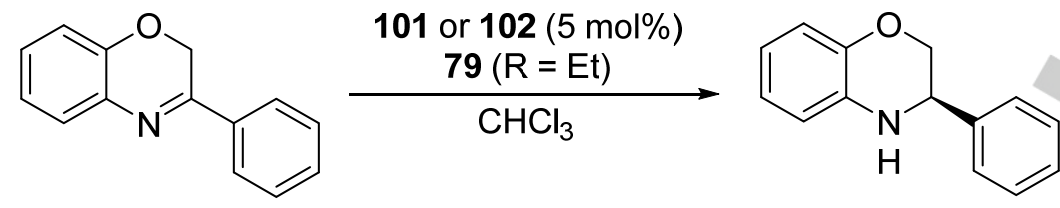

105

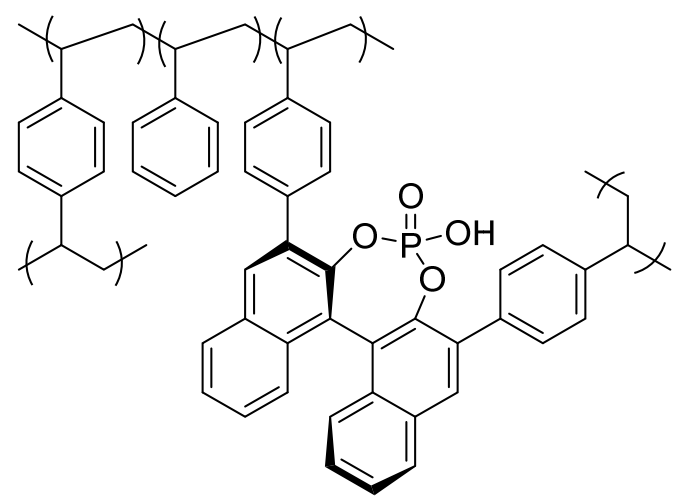

101
12 cycles: $87-97 \%$ yield

$94-96 \%$ ee
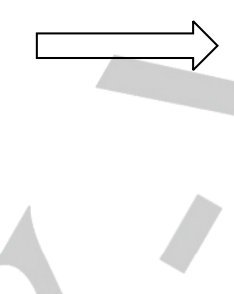

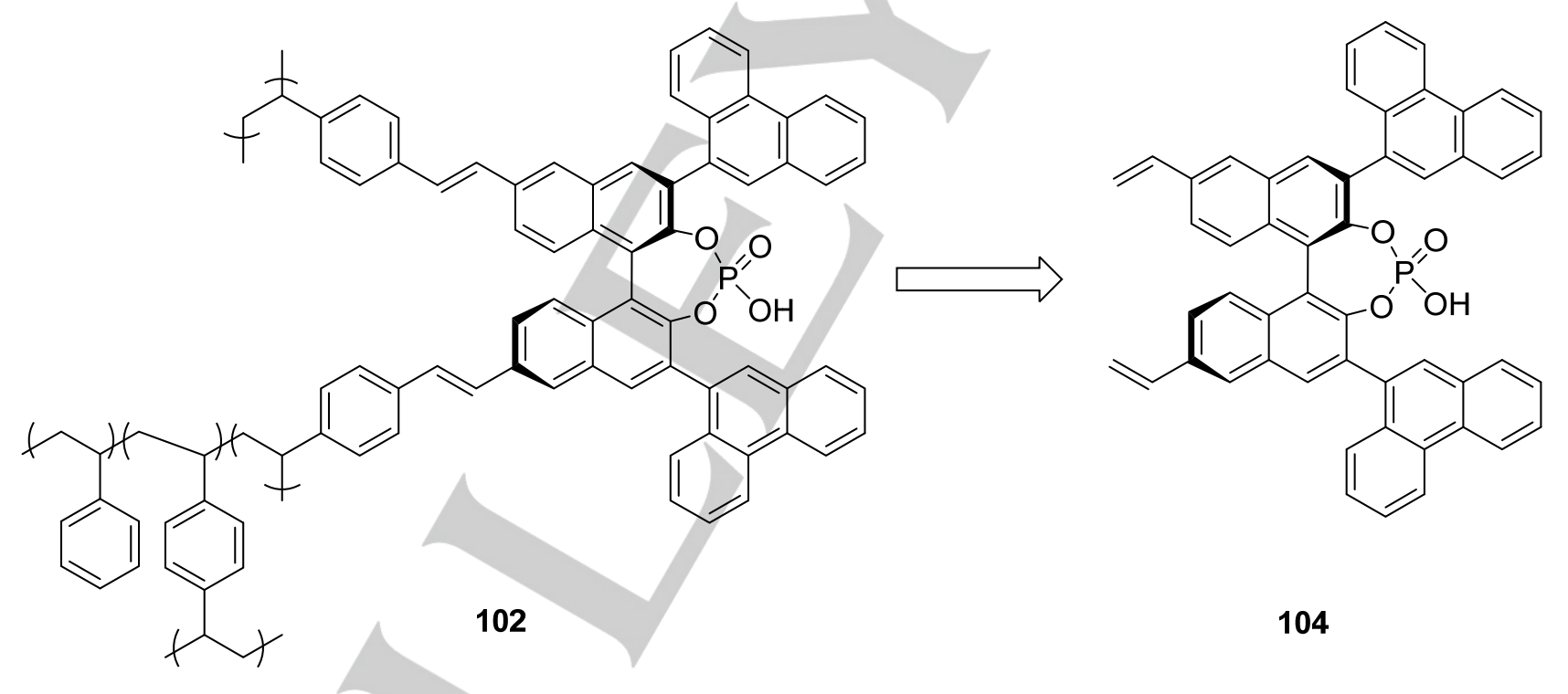<smiles>C=Cc1ccc(-c2cc3ccccc3c(-c3c4c(cc5ccccc35)OP(=O)(O)O4)c2-c2ccc(C=C)cc2)cc1</smiles>

103

Scheme 26. ATH of benzoxazine 105 using supported phosphoric acids. ${ }^{56}$ 
An interesting application of the ATH of imines is the organocatalyzed reductive amination of carbonyl compounds, in which an imine intermediate is reduced to the corresponding amine. In the case of methyl ketones 107, List et al. described the use of benzylamine in the reductive amination, using the Hantzsch ester $\mathbf{7 9}$ with $\mathrm{R}=\mathrm{Et}$, and the phosphoric acid $\mathbf{7 8}$ with $\mathrm{R}=$ anthryl, in order to get the corresponding amines 108 with variable results (Scheme 27). ${ }^{57}$ The benzyl group is easily removed by standard hydrogenation catalyzed by palladium on coal.

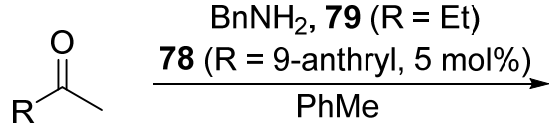

107<smiles>[R]C(C)[Hg]Br</smiles>

108

$59-96 \%$ yield, $26-88 \%$ ee

$$
\left[\mathrm{R}=i-\mathrm{Pr}, \mathrm{Ph}, 4-\mathrm{ClC}_{6} \mathrm{H}_{4}, \mathrm{Ph}\left(\mathrm{CH}_{2}\right)_{2}\right]
$$

Scheme 27. Reductive amination of ketones $107 .^{57}$

The same process, but catalyzed by the nucleotide adenosine diphosphate (ADP) 109 and aromatic amines, was developed by Kumar et al. obtaining the corresponding chiral amines with excellent yields (85-96\%) and enantioselectivities (75-89\% ee). ${ }^{58}$

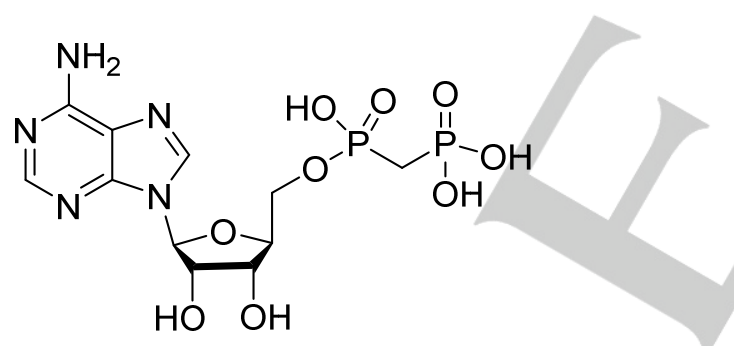

$$
109^{58}
$$

One interesting aspect of the ATH of imines is the dynamic kinetic resolution (DKR), which was studied by Zhou et al. for quinolines 110, using the Hantzsch ester 111, and the phosphoric acid 112, in order to get the expected products 113 with variable yields and high diastereo- and enantioselectivities (Scheme 28). ${ }^{59}$
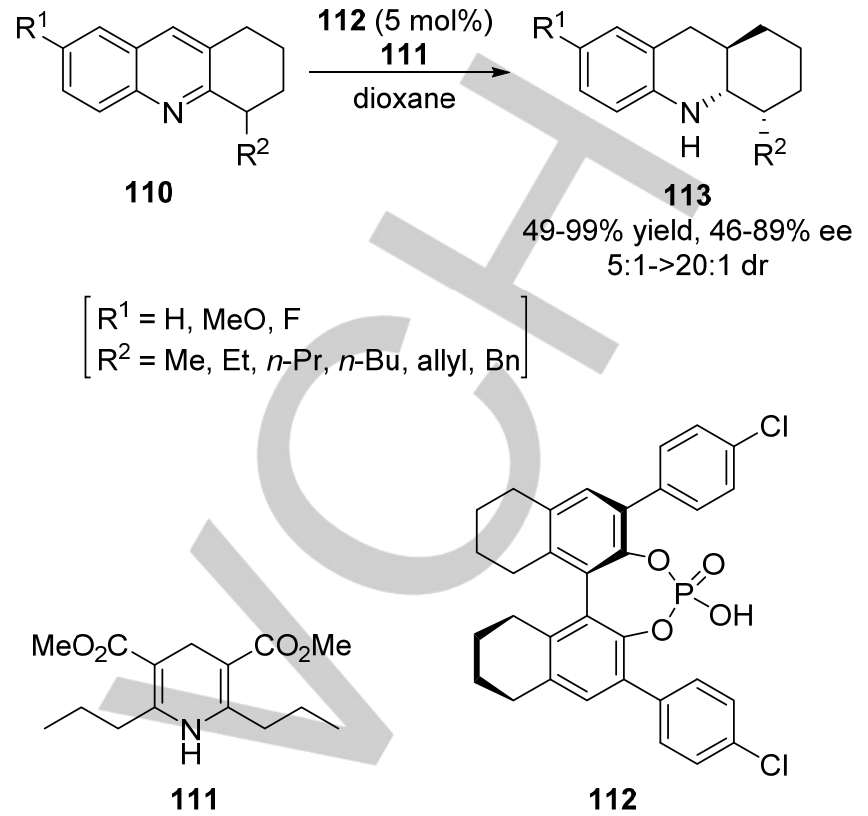

Scheme 28. Preparation of compounds 113 by a DKR. ${ }^{59}$

List et al. applied the same principle of DKR to the reductive amination of 2-substituted cyclohexanones 114 with $p$-anisidine, using the phosphoric acid 78 with $\mathrm{R}=2,4,6-i-\mathrm{Pr}_{3}$, and the ester 78 with $\mathrm{R}=\mathrm{Et}$, in order to obtain the expected amines 115 with excellent results (Scheme 29) ${ }^{60}$ This methodology has been applied to cyclopentanone derivatives with lower diastereoselectivity (1.6:1 for 2-n-butylcyclopentanone). In addition, the aryl group attached to the nitrogen atom is easily removed under oxidative conditions (CAN).

${ }^{\mathrm{O}}$ 78

114<smiles>[R]C1CCCCC1Nc1ccc(OC)cc1</smiles>

115

$63-91 \%$ yield, $88-96 \%$ ee $5: 1->99: 1 \mathrm{dr}$

$\left[\mathrm{R}=\mathrm{Me}, \mathrm{Et}, n-\mathrm{Pr}\right.$, allyl, 1-cyclohexenyl, $\mathrm{Ph}, \mathrm{Bn}, 2$-furyl, 3-MeOC $\left.{ }_{6} \mathrm{H}_{4}, \mathrm{Cl}\right]$

Scheme 29. Preparation of amines 115 by a DKR. ${ }^{60}$

The origin of the enantioselectivity in the DKR of $\alpha$-branched aldehydes, through a reductive amination with $p$-anisidine, in the presence of a Hantzsch ester 79 and the phosphoric acid 78 with $\mathrm{R}=2,4,6-i-\mathrm{Pr}_{3} \mathrm{C}_{6} \mathrm{H}_{2}$, was studied theoretically, and the computational model could explain the observed results. ${ }^{61}$

When the DKR was applied to the benzodiazepines 116, the corresponding mixture of diastereomers $\mathbf{1 1 7}$ was obtained, the syn-isomer being the major one. For this process, the Hantzsch ester 79 with $R=$ allyl, and the phosphoric acid 78 wit $R=P h$, were used in chloroform (Scheme 30). ${ }^{62}$ 


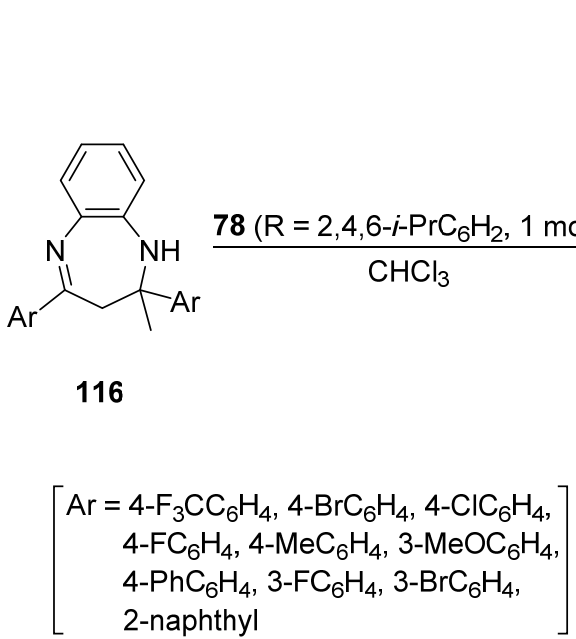
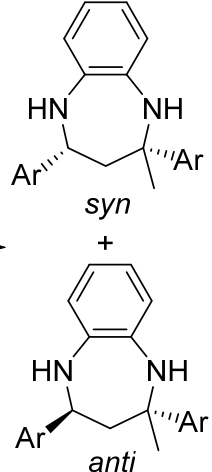

117

$63-97 \%$ yield $63-86 \%$ ee syn 2:1-8:1 dr
Scheme 30. Preparation of compounds 117 by a DKR. ${ }^{62}$

The ATH has also been applied to functionalized quinolines in order to prepare diastereo- and enantioselectively tetrahydroquinolines. Thus, this methodology was used for quinolines bearing a sulfonamido, ${ }^{63}$ trifluoromethyl, ${ }^{64}$ nitro, ${ }^{65}$ or fluoro $^{66}$ substituents mainly at the 3 -position, working with a Hantzsch ester 79 and a phosphoric acid 78 with different substitution at the 3 and 3 ' positions. In general, yields, diastereo- and enantioselectivities are high.

As it has been shown in this review up to now, the most commonly hydrogen source in the organocatalyzed ATH are the Hantzsch esters 79. However, Schreiner et al. reported the ATH of acetophenone imines 118, using trichlorosilane as hydrogen donor, and the proline derivative $\mathbf{1 1 9}$ as the chiral catalyst. The corresponding amines $\mathbf{1 2 0}$ were obtained with good yields but modest enantioselectivities (Scheme 31). ${ }^{67}$

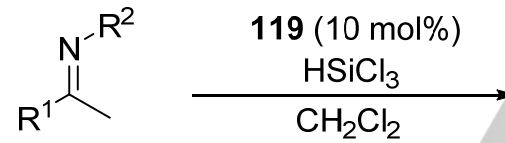

118

$$
\mathrm{R}^{1 \stackrel{H}{*}}
$$

120

$66-95 \%$ yield, $37-63 \%$ ee
$\left[\begin{array}{l}\mathrm{R}^{1}=\mathrm{Ph}, 4-\mathrm{MeC}_{6} \mathrm{H}_{4}, 4-\mathrm{F}_{3} \mathrm{CC}_{6} \mathrm{H}_{4} \\ \mathrm{R}^{2}=\mathrm{Ph}, 4-\mathrm{MeOC}_{6} \mathrm{H}_{4}, 4-\mathrm{ClC}_{6} \mathrm{H}_{4}, 3,5-\mathrm{Me}_{2} \mathrm{C}_{6} \mathrm{H}_{3}\end{array}\right]$

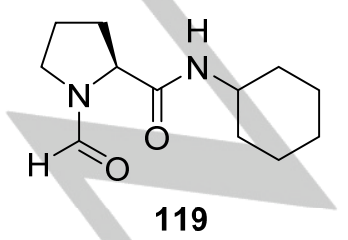

125
122

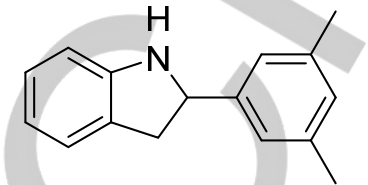

$121^{68}$
Finally, intra and intermolecular cascade ATH reactions have been reported. List et al. studied mechanistically the intramolecular version of this process by characterization of the intermediates by electrospray ionization mass spectrometry. Scheme 30 exemplifies this transformation of the diketone 122 into the amine 123 by a cascade ATH. ${ }^{69}$

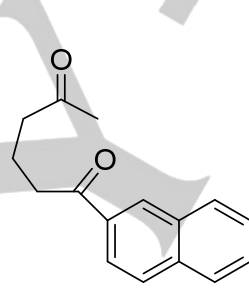

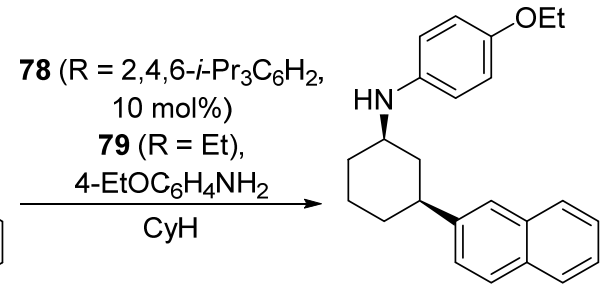

123
2:1 dr

Scheme 32. Transformtion of diketon 122 into the amine 123 by a cascade $\mathrm{ATH}{ }^{69}$

Concerning the intermolecular version of this process, Rueping et al. reported the reaction of enamines 124 with enones 125 under organocatalyzed conditions, yielding substituted tetrahydropyridines 126, with variable yields and excellent enantioselectivities (Scheme 33). ${ }^{70}$

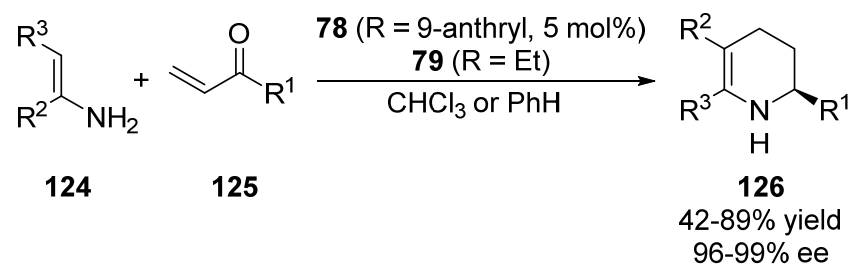

$\left[\begin{array}{l}R^{1}=4-\mathrm{MeOC}_{6} \mathrm{H}_{4}, 4-\mathrm{BrC}_{6} \mathrm{H}_{4}, 4-\mathrm{F}_{3} \mathrm{CC}_{6} \mathrm{H}_{4}, 4-\mathrm{FC}_{6} \mathrm{H}_{4} \\ \mathrm{R}^{2}=\mathrm{Me} \\ \mathrm{R}^{3}=\mathrm{NC}, \mathrm{MeCO}, \mathrm{MeO}_{2} \mathrm{C} ; \mathrm{R}^{2}-\mathrm{R}^{3}=\mathrm{CO}\left(\mathrm{CH}_{2}\right)_{3}\end{array}\right]$

Scheme 33. Preparation of cyclic enamines $126{ }^{70}$ 


\section{Enzymatic Reactions}

To the best of our knowledgement there is one only report on the use of human carbonic anhydrase II (hCAll) in combination with several sulfamide-bearing IrCp* complexes $\mathbf{1 2 7 - 1 3 0}$ for the ATH of imines. X-ray studies revealed the existence of critical cofactor-protein interactions, which could be genetically optimized in order to improve the catalytic performance of the artificial enzyme. $^{71}$

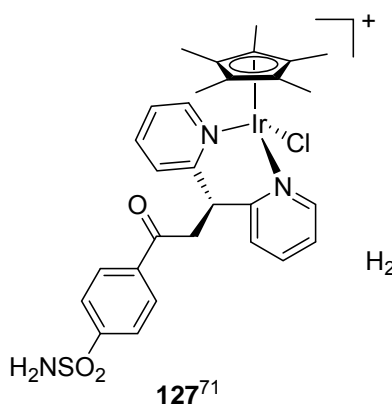

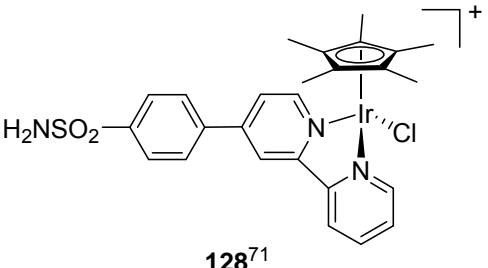

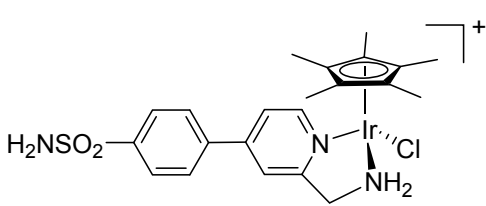

$129^{71}$

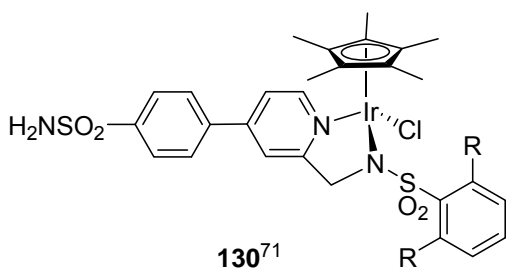

$[\mathrm{R}=\mathrm{H}, \mathrm{F}]$

00006, CTQ2011-24151, CTQ2011-24165), the Ministerio de Economía y Competitividad (MINECO) (projects CTQ201343446-P, CTQ2014-51912-REDC, CTQ2014-53695-P), FEDER, the Generalitat Valenciana (PROMETEO 2009/039, PROMETEOII/2014/017), and the University of Alicante.

Keywords: imines; transfer hydrogenation; metal-catalysis; organocatalysis; chiral amines

[1] Modern Reduction Methods (Eds.: P. G. Andersson, I. J. Munslow); Wiley-VCH: Weinheim, 2008.

[2] M. Wills, In reference [1]; pp. 271-296.

[3] M. Breuer, K. Ditrich, T. Habicher, B. Hauer, M. Kesseler, R. Stroemer, T. Zelinski, Angew. Chem. Int. Ed. 2004, 43, 788-824.

[4] R. Noyori, S. Hashiguchi, Acc. Chem. Res. 1997, 30, 97-102.

[5] C. Wang, X. Wu, J. Xiao, Chem. Asian J. 2008, 3, 1750-1770.

[6] a) R. Noyori, Angew. Chem. Int. Ed. 2002, 41, 2008-2022; b) W. S. Knowles, R. Noyori, Acc. Chem. Res. 2007, 40, 1238-1239.

[7] J. Wáclavíc, P. Kacer, M. Kuzma, L. Cerveny, Molecules 2011, 16, 5460-5495.

[8] Z. Wu, M. Perez, M. Scalone, T. Ayad, V. Ratovelomanana-Vidal, Angew. Chem. Int. Ed. 2013, 52, 4925-4928.

[9] M. Wu, T. Cheng, M. Ji, G. Liu, J. Org. Chem. 2015, 80, 3708-3713.

[10] P. Sot, B. Vilhanová, J. Pechácek, J. Václavík, J. Zápal, M. Kuzma, P. Kacer, Tetrahedron: Asymmetry 2014, 25, 1346-1351.

[11] J. Prech, J. VáclavíK, P. Sot, J. Pechácek, B. Vilhanová, J. Januscák, K Syslová, R. Pazout, J. Maixner, J. Zápal, M. Kuzma, P. Kacer, Catal. Commun. 2013, 36, 67-70

[12] a) J. Václavík, M. Kuzma, J. Prech, P. Kacer, Organometallics 2011, 30 4822-4829; b) J. Pechácek, J. Václavík, J. Prech, P. Sot, J. Januscák, B. Valhanová, J. Vavrik, M. Kuzma, P. Kacer, Tetrahedron: Asymmetry 2013, 24, 233-239; c) J. Václavík, J. Pechácek, B. Vilhanová, P. Sot, J. Januscák, V. Matousek, J. Prech, S. Bártová, M. Kuzma, P. Kacer, Catal. Lett. 2013, 143, 555-562.

[13] P. Sot, M. Kuzma, J. Václavík, K. Pechácek, J. Prech, J. Kanuscák, P. Kacer, Organometallics 2012, 31, 6496-6499.

[14] a) V. Parekh, J. A. Ramsden, M. Wills, Tetrahedron: Asymmetry 2010, 21, 1549-1556; b) for an account on iridium-catalyzed ATH of quinolines, see: D.-W. Wang, D.-S. Wang, Q.-A. Chen, Y.-G. Zhou, Chem. Eur. J. 2010, 16, 1133-1136.

[15] J. E. D. Martins, M. A. Contreras, M. Wills, Tetrahedron: Asymmetry 2010, 21, 2258-2264.

\section{Conclusions}

[16] J. E. D. Martins, G. J. Clarkson, M. Wills, Org. Lett. 2009, 11, 847-850.

[17] a) R. Soni, F. K. Cheung, G. C. Clarkson, J. E. D. Martins, M. A. Graham, M. Wills, Org. Biomol. Chem. 2011, 9, 3290-3294; b) V. Parkh, J. A. Ramsden, M. Wills, Catal. Sci. Technol. 2012, 2, 406-414.

From the recent developments of the ATH of imines we can conclude that for metal catalysis ruthenium is the metal of choice together with the monotosylated chiral 1,2-diamine TsDPEN. More recently, the organocatalysis using a Hantzsch ester and a chiral phosphoric acid derived from BINOL played the most important role in the ATH of imines. As a general conclusion, we think that this methodology is a convenient, versatile and environmentally friendly procedure to generate chiral amines using simple manipulation and commercially available reagents.

\section{Acknowledgements}

We thank the continue financial support from our Ministerio de Ciencia e Innovación (MICINN) (projects CTQ2007-62771/BQU, CTQ2010-20387, CONSOLIDER INGENIO 2010-CDS2007-

[18] P. Roszkowski, J. K. Maurin, Z. Czarnocki, Tetrahedron: Asymmetry 2013, 24, 643-650.

[19] H. Matsunaga, K. Nakanishi, M. Nakajima, T. Kunieda, T. Ishizuka, Heterocycles 2009, 78, 617-622.

[20] J. F. Collados, E. Toledano, D. Guijarro, M. Yus, J. Org. Chem. 2012 $77,5744-5750$.

[21] See, for instance: B. Denolf, S. Mangelinckx, K. W. Toernroos, N. De Kimpe, Org. Lett. 2006, 8, 3129-3132.

[22] a) D. Guijarro, O. Pablo, M. Yus, Tetrahedron Lett. 2009, 50, 53865388; b) D. Guijarro, O. Pablo, M. Yus, J. Org. Chem. 2010, 75, 52655270

[23] a) D. Guijarro, O. Pablo, M. Yus, Tetrahedron Lett. 2011, 52, 789-791; b) O. Pablo, D. Guijarro, G. Kovács, A. Lledós, G. Ujaque, M. Yus, Chem. Eur. J. 2012, 18, 1969-1983; c) D. Guijarro, O. Pablo, M. Yus, Org. Synth. 2013, 90, 338-349; d) O. Pablo, D. Guijarro, M. Yus, Eur. J. Org. Chem. 2014, 7034-7038.

[24] O. Pablo, D. Guijarro, M. Yus, J. Org. Chem. 2013, 78, 9181-9189. 
[25] D. Guijarro, O. Pablo, M. Yus, J. Org. Chem. 2013, 78, 3647-3654.

[26] O. Pablo, D. Guijarro, M. Yus, Appl. Sci. 2012, 2, 1-12.

[27] a) J. Li, Y. Zhang, D. Han, Q. Gao, C. Li., J. Mol. Catal. A: Chem. 2009, 298, 31-35; b) X. Gao, R. Liu, D. Zhang, M. Wu, T. Cheng, G. Liu, Chem. Eur. J. 2014, 20, 1515-1519.

[28] R. Liu, T. Cheng, L. Kong, C. Chen, G. Liu, H. Li, J. Catal. 2013, 307, 55-61.

[29] a) N. Haraguchi, K. Tsuro, Y. Arakawa, S. Itsuno, Org. Biomol. Chem. 2009, 7, 69-75; b) N. Haraguchi, A. Nishiyama, S. Itsuno, J. Polym. Sci.: A Polym. Chem. 2010, 48, 3340-3349; c) for an account on polymer-supported iridium complexes in ATH, see: S. Itsuno, $\mathrm{Y}$. Hashimoto, N. Haraguchi, J. Polym. Sci.: Part A: Polym. Chem. 2014, 52, 3037-3044.

[30] H. Sugie, Y. Hashimoto, N. Haraguchi, S. Itsuno, J. Organomet. Chem. 2014, 751, 711-716.

[31] R. A. Pilli, M. T. Rodrigues Jr, J. Braz. Chem. Soc. 2009, 20, 14341440.

[32] H.-K. Lee, S. Kang, E. B. Choi, J. Org. Chem. 2012, 77, 5454-5460.

[33] Y. Takahashi, H. Ishiyama, T. Kubota, J. Kobayashi, Biorg. Med. Chem. Lett. 2010, 20, 4100-4103.

[34] D. S. Matharu, J. E. D. Martins, M. Wills, Chem. Asian J. 2008, 3, 13741383.

[35] C. Wang, C. Li, X. Wu, A. Pettman, J. Xiao, Angew. Chem. Int. Ed. 2009, 48, 6524-6528.

[36] L. Wang, Q. Zhou, C. Qiu, Q. Wang, L. Cun, J. Zhu, J. Deng, Tetrahedron 2013, 69, 6500-6506.

[37] S. Kang, J. Han, E. S. Lee, E. B. Choi, H.-K. Lee, Org. Lett. 2010, 12, 4184-4187.

[38] J. Hang, S. Kang, H.-K. Lee, Chem. Commun. 2011, 47, 4004-4006.

[39] J.-a. Kim, Y. J. Seo, S. Kang, J. Han, H.-K. Lee, Chem. Commun. 2014, 50, 13706-13709.

[40] a) V. S. Shende, S. K. Shingote, S. H. Deshpande, N. Kuriakose, K Vanka, A. A. Kelkar, RSC Adv. 2014, 4, 46351-46356; b) for an account on ATH of cyclic imines in water, see: V. S. Shende, S. H. Deshpande, S. K. Shingote, A. Joseph, A. K. Kelkar, Org. Lett. 2015, 17, 2878-2881.

[41] a) A. A. Mikhailine, M. I. Maishan, R. H. Morris, Org. Lett. 2012, 14, 4638-4641; b) W. Zuo, A. J. Lough, Y. F. Li, R. H. Morris, Science 2013, 342, 1080-1083; c) P. E. Sues, K. Z. Demmans, R. H. Morris, Dalton Trans. 2014, 43, 7650-7667.

[42] a) S. Zhou, S. Fleischer, K. Junge, S. Das, D. Addis, M. Beller, Angew. Chem. Int. Ed. 2010, 49, 8121-8125; b) S. Zhou, S. Fleischer, K. Junge, S. Das, D. Addis, M. Beller, Angew. Chem. Int. Ed. 2010, 49, 81218125.

[43] J. G. de Vries, N. Mrsic, Catal. Sci. Technol. 2011, 1, 727-735.

[44] C. Zhu, K. Saito, M. Yamanaka, T. Akiyama, Acc. Chem. Res. 2015, 48, 388-398.

[45] M. Rueping, E. Sugiono, F. R. Schoepke, Synlett 2010, 852-865

[46] G. Li, J. C. Antilla, Org. Lett. 2009, 11, 1075-1078.

[47] Q. Kang, Z.-A. Zhao, S.-L. You, Org. Lett. 2008, 10, 2031-2034.

[48] T. B. Nguyen, H. Bousserouel, Q. Wang, F. Guéritte, Org. Lett. 2010, 12, 4705-4707.
[49] M. Rueping, C. Brinkmann, A. P. Antonchick, I. Atodiresei, Org. Lett. 2010, 12, 4604-4607.

[50] a) M. Rueping, T. Theissmann, S. Raja, J. W. Bats, Adv. Synth. Catal. 2008, 350, 1001-1006; b) M. Rueping, T. Theissmann, M. Stoeckel, A. P. Antonchick, Org. Biomol. Chem. 2011, 9, 6844-6850.

[51] M. Rueping, T. Theissmann, Chem. Sci. 2010, 1, 473-476.

[52] M. Rueping, F. Tato, F. R. Schoepke, Chem. Eur. J. 2010, 16, 26882691.

[53] M. Rueping, E. Merino, R. M. Koenigs, Adv. Synth. Catal. 2010, 352, 2629-2634.

[54] Q.-S. Guo, D.-M. Du, J. Xu, Angew. Chem. Int. Ed. 2008, 47, 759-762.

[55] C. Metallinos, F. B. Barret, S. Xu, Synlett 2008, 720-724.

[56] M. Rueping, E. Sugiono, A. Steck, T. Theissmann, Adv. Synth. Catal. 2010, 353, 281-287.

[57] V. N. Wakchaure, M. Nicoletti, L. Ratjen, B. List, Synlett 2010, 27082710.

[58] A. Kumar, S. Sharma, R. A. Maurya, Adv. Synth. Catal. 2010, 352, 2227-2232

[59] M.-W. Chen, X.-F. Cai, Z.-P. Chen, L. Shi, Y.-G. Zhou, Chem. Commun 2014, 50, 12526-12529.

[60] V. N. Wakchaure, J. Zhou, S. Hoffmann, B. List, Angew. Chem. Int. Ed 2010, 49, 4612-4614

[61] T. Marcelli, P. Hammar, F. Himo, Adv. Synth. Catal. 2009, 351, 525529.

[62] Z.-Y. Han, H. Xiao, L.-Z. Gong, Bioorg. Med. Chem. Lett. 2009, 19, 3729-3732.

[63] X.-F. Cai, R.-N. Guo, G.-S. Feng, B. Wu, Y.-G. Zhou, Org. Lett. 2014 16, 2680-2683.

[64] R.-N. Guo, Z.-P. Chen, X.-F. Cai, Y.-G. Zhou, Synthesis 2014, 46, 2751-2756.

[65] X.-F. Cai, M.-W. Chen, Z.-S. Ye, R.-N. Guo, L. Shi, Y.-Q. Li, Y,-G. Zhou, Chem. Asian J. 2013, 8, 1381-1385.

[66] M. Rueping, M. Stoeckel, E. Sugiono, T. Theissmann, Tetrahedron 2010, 66, 6565-6568.

[67] Z. Zhang, P. Rooshenas, H. Hausmann, P. R. Schreiner, Synthesis 2009, 1531-1544.

[68] K. Saito, H. Miyashita, T. Akiyama, Org. Lett. 2014, 16, 5312-5315.

[69] W. Schrader, P. P. Handayani, J. Zhou, B. List, Angew. Chem. Int. Ed. 2009, 48, 1463-1466.

[70] M. Rueping, A. P. Antonchick, Angew. Chem. Int. Ed. 2008, 47, 58365839.

[71] F. W. Monnard, E. S. Nogueira, T. Heinisch, T. Schirmer, T. R. Ward Chem. Sci. 2013, 4, 3269-3274. 
Entry for the Table of Contents (Please choose one layout)

Layout 1:

\section{RECORD REVIEW}

Text for Table of Contents

Layout 2:

\section{RECORD REVIEW}

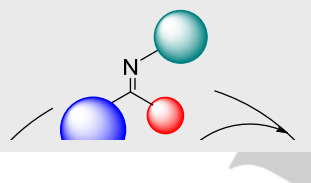

F. Foubelo, M. Yus

Page No. - Page No.

Catalytic Asymmetric Transfer Hydrogenation of Imines: Recent Advances

The ATH of imines has demonstrated to be a useful technique to access to chiral amines with high optical purity. The processes proceeded effectively under organometallic catalysis in the presence of a chiral ligand and using isopropanol or formic acid as the source of hydrogen. More recently, the organocatalysis using a Hantzsch ester and a chiral phosphoric acid derived from BINOL emerged as a environmentally friendly procedure alternative in the ATH of imines. 